\title{
Significance of graphite inclusion occurrence in the minerals of the San Miguel skarn for the Palaeoproterozoic basement of Tandilia Belt (Argentina) and for the Río de la Plata Craton
}

\author{
M.F. Lajoinie ${ }^{\mathrm{a}, \mathrm{b}}$, C.A. Ballivián Justiniano ${ }^{\mathrm{a}, \mathrm{b}}$, M.A. Salvioli ${ }^{\mathrm{a}, \mathrm{b}}$, R. Ruiz $^{\mathrm{b}, \mathrm{c}}$, C. Recio ${ }^{\mathrm{d}}$, A.N. Sial ${ }^{\mathrm{e}}$, \\ R.O. Etcheverry ${ }^{\mathrm{a}, \mathrm{b}}$, M.V. Curci ${ }^{\mathrm{a}}$, H.G. de la Cal ${ }^{\mathrm{f}}$, M.E. Lanfranchini ${ }^{\mathrm{a}, \mathrm{g}, *}$ \\ ${ }^{a}$ Instituto de Recursos Minerales, Facultad de Ciencias Naturales y Museo, Universidad Nacional de La Plata (INREMI-FCNyM-UNLP), Calle 64 N ${ }^{\circ}$, CP1900, Argentina \\ ${ }^{\mathrm{b}}$ Consejo Nacional de Investigaciones Científicas y Técnicas (CONICET), Godoy Cruz N²290, Buenos Aires, Argentina \\ ${ }^{\mathrm{c}}$ YPF Tecnología (Y-TEC), Avenida del Petróleo Argentino N ${ }^{\circ}$ 900-1198, Buenos Aires, Argentina \\ ${ }^{\mathrm{d}}$ Departamento de Geología, Facultad de Ciencias, Universidad de Salamanca, Plaza Caídos, s/n, CP37008, Spain \\ ${ }^{\mathrm{e}}$ Department of Geology, Federal University of Pernambuco, NEG-LABISE, Recife, Brazil \\ ${ }^{\mathrm{f}}$ ROCH S.A, Avenida Madero 1020, Piso 21, C1106ACX, CABA, Argentina \\ ${ }^{\mathrm{g}}$ Comisión de Investigaciones Científicas de La Provincia de Buenos Aires (CICBA), Calle 532 e/ 10 y 11, La Plata, Argentina
}

A R T I C L E IN F O

\section{Keywords:}

Río de la Plata Craton

"Lomagundi-Jatuli event"

Metasomatism

Fluid inclusions

Raman spectroscopy

Syngenetic graphite

\begin{abstract}
A B S T R A C T
Graphite in Archaean-Palaeoproterozoic rocks has been a subject of interest since it could represent an evidence of early life on Earth. In the Palaeoproterozoic basement of the Tandilia Belt, graphite was found both in fluid inclusions (FI) hosted in the San Miguel skarn calc-silicate minerals, and as solid inclusions in calcite crystals from the protolithic marble ( $\mathrm{a}^{13} \mathrm{C}$ enriched carbonate from the "Lomagundi-Jatuli event"). FI microthermometry and oxygen stable isotope ratios indicated the skarn minerals formation within the range of $630-650^{\circ} \mathrm{C}$ (at $\sim 5 \mathrm{kbars}$ ) and $\sim 642-654^{\circ} \mathrm{C}$, respectively. Also, the characterisation of the metasomatic fluid (of a low salinity $<7 \mathrm{wt} \% \mathrm{NaCl}$ eq. $\mathrm{NaCl}-\mathrm{H}_{2} \mathrm{O} / \mathrm{NaCl}-\mathrm{KCl}-\mathrm{H}_{2} \mathrm{O}$ aqueous system) pointed out that the zonal crystallisation pattern shown by the skarn minerals (wollastonite-vesuvianite, grossular-diopside-calcite and diopside-calcite zones in the exoskarn, and grossular-diopside and diopside-calcic plagioclase zones in the endoskarn) responds to the increase of the involved cation activity gradients $\left(\mathrm{Ca}^{2+}-\mathrm{Si}^{4+}-\mathrm{Mg}^{2+}-\mathrm{Fe}^{2+/ 3+}-\mathrm{Al}^{3+}\right)$ and not to significant changes in the temperature or concentration of $\mathrm{CO}_{2}$ in the system. Variation in the crystallinity degree of the graphite hosted in the skarn minerals and in marble calcite, shown by Raman spectroscopy, would indicate that the graphite could have been formed from the ripening of organic matter present in the sedimentary rocks during the metamorphic-metasomatic event (Transamazonian Orogeny). In this sense, the increase of the organic carbon productivity in the oceans during the Palaeoproterozoic, represented by the "Lomagundi-Jatuli event", would support this graphite origin and also the possible existence of a marine sedimentary basin in the previous stages of the Río de la Plata amalgamation (Siderian-Rhyacian), in the San Miguel area of the Tandilia Belt.
\end{abstract}

\section{Introduction}

The study of Archaean-Palaeoproterozoic rocks has allowed the most important events and processes that occurred in the early evolution of the Earth to be reconstructed. In particular, the presence of graphite in these rocks has been the focus of several investigations, given that this carbonaceous material could be early evidence of life that has been together affected with the host sedimentary strata by metamorphic processes (Tazaki et al., 1992; Schidlowski, 1995;
Dissanayake et al., 2000). However, graphite may also result from carbon-bearing fluids precipitation not involving organic matter (Santosh and Wada, 1993; Luque et al., 1998, 2012). Thus, graphite present in ancient rocks must be carefully studied in order to determine its origin.

The Palaeoproterozoic basement of the Tandilia Belt, Buenos Aires province (Argentina), hosts two skarn deposits: Punta Tota (Delpino, 2000; Delpino and Dristas, 2008) located nearby Balcarce city, and San Miguel (Lajoinie, 2015; Lajoinie et al., 2013, 2017a), situated SW of

\footnotetext{
* Corresponding author. Instituto de Recursos Minerales (INREMI), Universidad Nacional de La Plata-Comisión de Investigaciones Científicas de la Provincia de Buenos Aires, Calle 64 esquina 120, 1er piso, C.P. 1900, La Plata, Argentina.

E-mail address: lanfranchini@yahoo.com (M.E. Lanfranchini).
} 
Tandil city. The presence of the above-mentioned skarns reveals the occurrence of particular geological and geochemical processes for this area. In this sense, the study and understanding of the processes that originated these deposits contribute to the reconstruction of the Tandilia Belt genesis and evolution. Recently, Lajoinie et al. (2018) defined the San Miguel skarn protolith as a marine carbonate deposited during the Palaeoproterozoic "Lomagundi-Jatuli event", largely following the recognition of an important $\delta^{13} \mathrm{C}_{\mathrm{V} \text {-PDB }}$ positive anomaly $(>+5 \%$ ). This discovery points out that the San Miguel area is key for the reconstruction of the processes and geological environments that occurred before and during the Transamazonian Orogeny.

In this context, mineral chemistry analyses, microthermometric studies, and Raman spectroscopy in fluid inclusions and stable isotope $\left(\delta^{18} \mathrm{O}_{\mathrm{V}-\mathrm{SmOW}}\right)$ determinations in different calc-silicates are reported in order to characterise the physicochemical and geological conditions, and the nature of metasomatic fluids that affected this portion of the basement resulting in the San Miguel skarn formation. On the other hand, the recognition of graphite in these metamorphic rocks of Palaeoproterozoic age is highlighted due to its possible use as an ancient-sedimentary-basin geomarker (Siderian-Rhyacian age) and for its implication in the tectonic configuration of the Río de la Plata Craton southern margin.

\section{Regional geology}

\subsection{Río de la Plata Craton}

The Río de la Plata Craton (RPC) occurs in Piedra Alta terrane (western Uruguay), Tandilia Belt and Martín García Island (centraleastern Argentina), and is composed by Rhyacian units (Almeida et al., 1973; Oriolo et al., 2016a and b; Oyhantçabal et al., 2018 and references therein; Fig. 1a). However, some authors proposed an extension of the RPC limits further north on the basis of existing isotopic data integration (Fig. 1a; Santos et al., 2017b). In this sense, the RPC could be formed by dominant Rhyacian rocks, but also by Archaean nuclei and Sthaterian and Mesoproterozoic rocks (Mallmann et al., 2007; Bossi and Cingolani, 2009; Cingolani, 2011; Gaucher et al., 2011; Camozzatto et al., 2013; Santos et al., 2017b).

Although the RPC limits continue to be defined, its most important evolution and growth occurred during the Transamazonian or Transplatense Orogen (2050-2250 Ma) (Santos et al., 2017b).

In Argentina, the RPC crops out in the Tandilia Belt region (Cingolani, 2011) and at Martín García Island (Dalla Salda et al., 2005; Santos et al., 2017a). Even though the RPC southern part genesis is still a debated subject, some models indicate that its evolution involves the amalgamation of three parautochthonous terranes: Buenos Aires-Piedra Alta (BA-PA), Tandilia, and Balcarce (Chernicoff et al., 2014), formed during an extension of Neoarchaean crust which caused the terranes separation and the development of narrow oceans in between (Lajoinie et al., 2018; Oyhantçabal et al., 2018 and references therein). The final re-accretion would have occurred during the Rhyacian Orogeny, which caused the formation of two sutures after the terranes collision (Fig. 1a; Chernicoff et al., 2014).

\subsection{Tandilia Belt}

It is constituted by a group of low hills located in the central-eastern region of Argentina, which extends along $350 \mathrm{~km}$ in a NW-SE direction (Fig. 1a). Its basement, assigned to the Buenos Aires Complex (Marchese and Di Paola, 1975), is mainly exposed in the northern sector of the belt (Fig. 1b). It corresponds to a metamorphic-igneous association composed of granitic-tonalitic gneisses, migmatites, amphibolites, subordinated schist, marbles and low-grade metamorphic rocks, together with acidic to basic igneous bodies (Dalla Salda et al., 2005; Cingolani, 2011).

Metamorphic rocks like biotite- and garnet-bearing gneisses are well-exposed and present SHRIMP $\mathrm{U}-\mathrm{Pb}$ ages in the range of 2.20 to 2.07 Ga (Chernicoff et al., 2015; Cingolani et al., 2002; Hartmann et al., 2002a and b). Migmatites, with $\mathrm{Rb}-\mathrm{Sr}$ age of $\sim 2.10 \mathrm{Ga}$ and $\mathrm{Sm}-\mathrm{Nd}$ age $\sim 2.15 \mathrm{Ga}$ (Pankhurst et al., 2003), are common in several sectors. Amphibolites composed of plagioclase, amphibole and quartz are present as lenses or nodules included in other metamorphic rocks, generally gneisses and migmatites, and also in igneous rocks. The marbles are scarce and have been identified in the San Miguel area (Fig. 1b; Quartino and Villar Fabre, 1967; Lajoinie et al., 2013; Lajoinie, 2015) and in Punta Tota, Sierra de Bachicha (Fig. 1b; Delpino and Dristas, 2008). In this last sector, the geothermobarometric data shows metamorphic conditions of $750-800^{\circ} \mathrm{C}$ and 5-6 kbar followed by an isobaric cooling to $450-500^{\circ} \mathrm{C}$ (Delpino and Dristas, 2008). Similar barometric data of 4.5-6.7 kbar and 5.8-7 kbar was obtained by Massonne (2012) and Martínez et al. (2016, 2017) respectively, in nearby sectors of the Balcarce area.

On the other hand, Teruggi et al. (1988) described a set of low-grade metamorphic rocks; El Cortijo Formation (metacherts, metabasalts and metawackes), of possible oceanic origin located at the southwest of Tandil city (Fig. 1b). Lajoinie et al. (2017b) recently studied metacherts, demonstrating that these rocks have geochemical signatures of seawater precipitates.

The granitoids are of varied composition and textures; they are hosted by gneisses and migmatites (Dalla Salda et al., 2005). They have predominantly Palaeoproterozoic $\mathrm{K}-\mathrm{Ar}$ ages between 2.2 and $2.00 \mathrm{Ga}$ (Hart et al., 1965; Halpern et al., 1970), a SHRIMP U-Pb age of $\sim 2.17$ Ga (Cingolani et al., 2002; Hartmann et al., 2002a and b) and $\mathrm{Rb}-\mathrm{Sr}$ ages between 2.16 and 1.8 Ga (Hart et al., 1965; Halpern et al., 1970; Varela et al., 1988; Linares and González, 1990; Pankhurst et al., 2003).

The basement was intruded by two dike sets (Iacumin et al., 2001). The first one has E-W orientation, calc-alkaline affinity, andesitic to rhyolitic composition and ${ }^{40} \mathrm{Ar}-{ }^{39} \mathrm{Ar}$ ages bracketed between $2.02 \pm 0.02 \mathrm{Ga}$ and $2.00 \pm 0.02 \mathrm{Ga}$ (Iacumin et al., 2001; Teixeira et al., 2013). The second set has a general $\mathrm{N} 30^{\circ} \mathrm{W}$ orientation, tholeitic affinity, basaltic to andesitic composition and U-Pb (ID-TIMS) baddeleyite ages of $\sim 1.58 \pm 3 \mathrm{Ga}$ (Teixeira et al., 2013). The genesis of both sets is associated with different stages of the Transamazonian Orogeny (Iacumin et al., 2001).

Overlaying the basement, a sedimentary calcareous-siliciclastic succession of Neoproterozoic age (800-500 Ma) and a siliciclastic one of Ordovician-Silurian age occur. The first succession includes Sierras Bayas and La Providencia Groups (Fig. 1b; Poiré, 1987; Gómez Peral, 2008; Arrouy et al., 2016a and b) and the second, the Balcarce Formation (Fig. 1b; Poiré et al., 2003; Zimmermann and Spalletti, 2009). The above-mentioned sedimentary cover was deposited in a marine platform environment (Poiré, 1987; Poiré et al., 2003).

The tectono-magmatic evolution of the Buenos Aires Complex corresponds mainly to the Transamazonian or Transplatense Orogeny of Rhyacian age $\sim 2.20-1.80$ Ga (Teruggi et al., 1973; Dalla Salda et al., 1988; Santos et al., 2017b). This period is linked to a continental collision episode (Cingolani, 2011; Martínez et al., 2016, 2017; Oyhantçabal et al., 2018), which generated deformation, metamorphism and crustal anatexis, and the consequent intrusion of granite bodies. This orogenic event was followed by a post collisional distensive stage between 1.80 and $1.60 \mathrm{Ga}$ (Cingolani, 2011).

\section{Background and geology of the study area}

San Miguel area is situated near Barker locality, southwest of Tandil city (Fig. 1b). Igneous and metamorphic rocks of the Buenos Aires Complex crop out in this area. Igneous rocks correspond to a graniticgranodioritic- and tonalitic pluton, which crop out in the Guacho and the Los Angelitos Hills, respectively (Lajoinie, 2015, Fig. 2a and b). The tonalite pluton also crops out at the San Miguel farm (Fig. 2a). In addition, granitic-granodioritic dikes, and a calc-alkaline andesitic- 


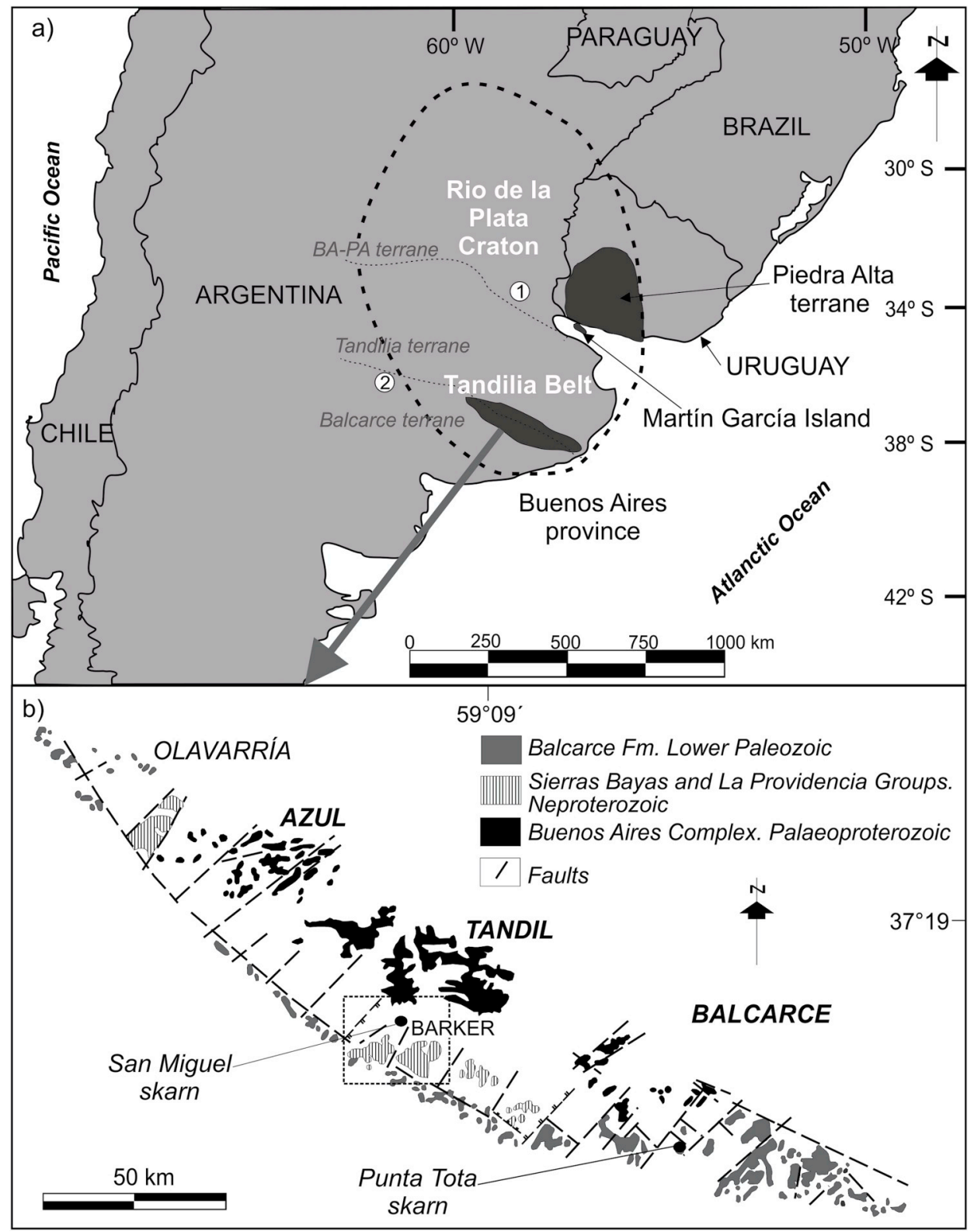

Fig. 1. a) Río de la Plata Craton schematic geological map. 1 and 2 sutures; BA-PA: Buenos Aires-Piedra Alta terrane. b) Tandilia Belt geological map, modified from Dalla Salda et al. (2005). Olavarría, Azul, Tandil and Balcarce regions and San Miguel and Punta Tota skarns outcrops are highlighted.

basaltic $\sim 2.00 \mathrm{Ga}$ old (Lajoinie et al., 2014a) were identified (Fig. 2a). The metamorphic rocks constitute a high-grade metamorphic association (upper amphibolite facies) integrated by a biotite gneiss and garnet migmatite (Fig. 2a and b) with an $\mathrm{Rb}-\mathrm{Sr}$ age of $\sim 2.12 \pm 0.01 \mathrm{Ga}$ (Halpern et al., 1970). Besides, a calcitic marble (Fig. 2a and b) with clinopyroxene crystals, whose protolith was interpreted as a Palaeoproterozoic marine carbonate $\left(\mathrm{T}_{\mathrm{DM}}=3.05-2.47 \mathrm{Ga}\right)$ deposited during the "Lomagundi-Jatuli event" (Melezhik et al., 2005), crops out in the area (Lajoinie et al., 2014b, 2018).

The San Miguel skarn was identified in three outcrops, referred to by Lajoinie et al. (2013) as north-west, north-east (NWS and NES, respectively; Fig. 3a), and south (SS) sectors (Fig. 3b). According to the genetic interpretations of Lajoinie (2015) and Lajoinie et al. (2017a), the San Miguel skarn was formed by the intrusion of numerous leucogranitic thin bodies derived from the garnet migmatites into the calcitic marble, which caused metasomatism. Detailed study of the mineralogical, textural and structural characteristics of the skarn in the NWS, allowed a mineral zonation to be determined. The defined zones correspond to: wollastonite-vesuvianite (marble-leucogranite contact), garnet-clinopyroxene-calcite and clinopyroxene-calcite, which form the exoskarn, and garnet-clinopyroxene and clinopyroxene-calcic plagioclase, which constitute the endoskarn (Fig. 3a and b).

Two new skarn outcrops located in La Concordia and Siempre Verde farms, are present in this work (Fig. 2a and b). The first one shows a clinopyroxene-calcic plagioclase zone similar to that described for the San Miguel skarn, while the following zones were recognised in the second one: wollastonite without vesuvianite and clinopyroxene in exoskarn facies, and clinopyroxene-calcic plagioclase in endoskarn facies (Fig. 3d).

\section{Analytical methods}

Petrographic studies were performed in a petro-calcographic microscope Nikon Optiphot-POL model at the Instituto de Recursos Minerales, Universidad Nacional de La Plata (INREMI-UNLP). Vesuvianite, garnet, clinopyroxene and quartz crystals with a higher 


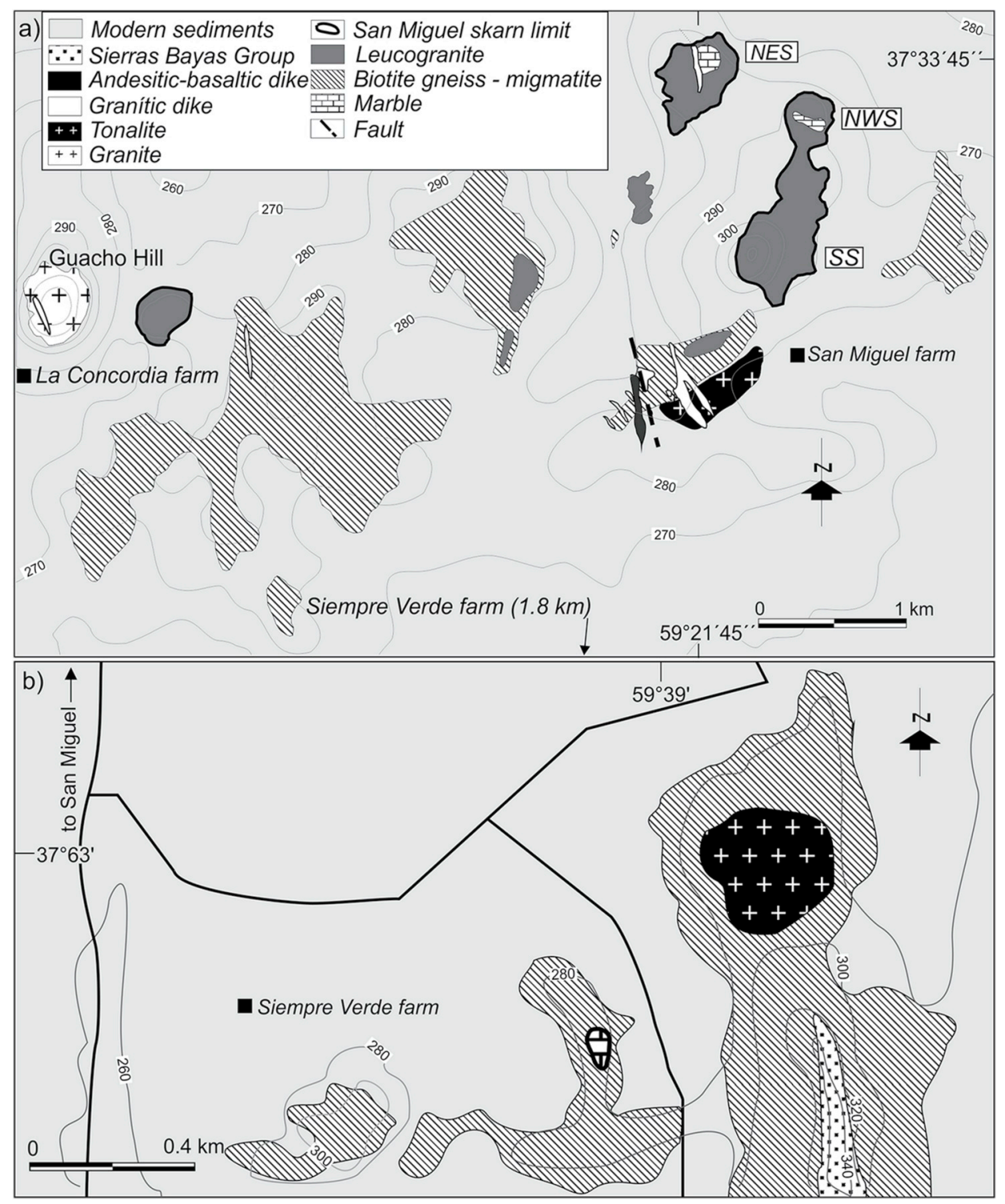

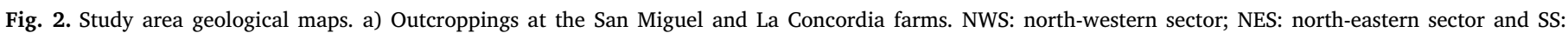
southern sector. b) Siempre Verde farm outcrops.

population of fluid inclusions (FI) were selected and chemically characterised using a Scanning Electron microscope (SEM) and an Electron Microprobe. The SEM analyses were performed in the centre and edge of isolated crystals, using an ESEM FEI Quanta 200, with tungsten filament coupled with an EDX (energy dispersive X-ray spectroscopy) Detector Apollo 40 at the Laboratorio de Investigaciones de Metalurgia Física-Universidad Nacional nude La Plata (LIMF-UNLP). The measurements were made under low vacuum and at two different pressures. The Electron Microprobe analyses of garnet and clinopyroxene crystals were made in a Cameca Camebax SX 100 model at the Servicio de Ciencia y Técnica de la Universidad de Oviedo, Spain. Operating conditions were $20 \mathrm{kV}$ accelerating voltage, beam current of $20 \mathrm{nA}$ and beam size of 1-2 $\mu \mathrm{m}$. Natural standards certificated by MAC (Micro Analysis Consultants Ltd. United Kingdom) were used for calculating element concentrations: albite for $\mathrm{Na}$ and $\mathrm{Si}, \mathrm{Al}_{2} \mathrm{O}_{3}$ for $\mathrm{Al}, \mathrm{MgO}$ for $\mathrm{Mg}$, andradite for $\mathrm{Ca}$, orthoclase for $\mathrm{K}$, synthetic $\mathrm{Mn}$ and $\mathrm{Ti}$ oxides for $\mathrm{Mn}$ and $\mathrm{Ti}$, magnetite for $\mathrm{Fe}, \mathrm{NiO}$ for $\mathrm{Ni}$ and chromite for $\mathrm{Cr}$.

FI genetic classification was made according to Nash (1976) and Roedder (1984) classifications. Microthermometric studies were performed at the Departamento de Geología de la Universidad de Buenos Aires using a Linkam warming-cooling plate installed on a Leica microscope, and at the INREMI-UNLP employing a Linkam THM600 which allows to operate between $-196^{\circ} \mathrm{C}$ (with LNP95) and $600^{\circ} \mathrm{C}$,

In order to determine the gas phase composition, FI were analysed using Raman spectroscopy at the YPF Tecnología (Y-Tec) lab. Raman spectra were obtained using a Jasco NRS-4100 spectrograph, equipped with a $532 \mathrm{~nm}$ laser (with a power of $20 \mathrm{~mW}$ resulting in $\sim 8.1 \mathrm{~mW}$ in the sample), vertically polarized and with a set of holographic filters coupled to an Olympus microscope system which focuses the laser on the sample using a 20x objective (N.A.: 0.40 ) and collecting the retro dispersed signal. The diameter of the area analysed with the laser is about $1.5 \mu \mathrm{m}$, with a measuring range of $50-4000 \mathrm{~cm}^{-1}$, acquisition time of $5 \mathrm{~s}$ and a set of $5-10$ accumulations to obtain a satisfactory spectrum, optimizing the signal-noise $(\mathrm{S} / \mathrm{N})$ ratio. The silicon standard was used to calibrate the equipment.

Oxygen isotope ratios were determined on wollastonite, vesuvianite, garnet and clinopyroxene crystals, previously separated and concentrated under a binocular microscope. The analyses were performed on $\mathrm{CO}_{2}$ generated by laser fluorination (Clayton and Mayeda, 1963) employing a $25 \mathrm{~W} \mathrm{CO}$ laser (Sharp, 1990) and $\mathrm{ClF}_{3}$ as reagent (Borthwick and Hasmon, 1982) at the Servicio General de Análisis de Isótopos Estables of the Universidad de Salamanca (Spain), using a VG- 


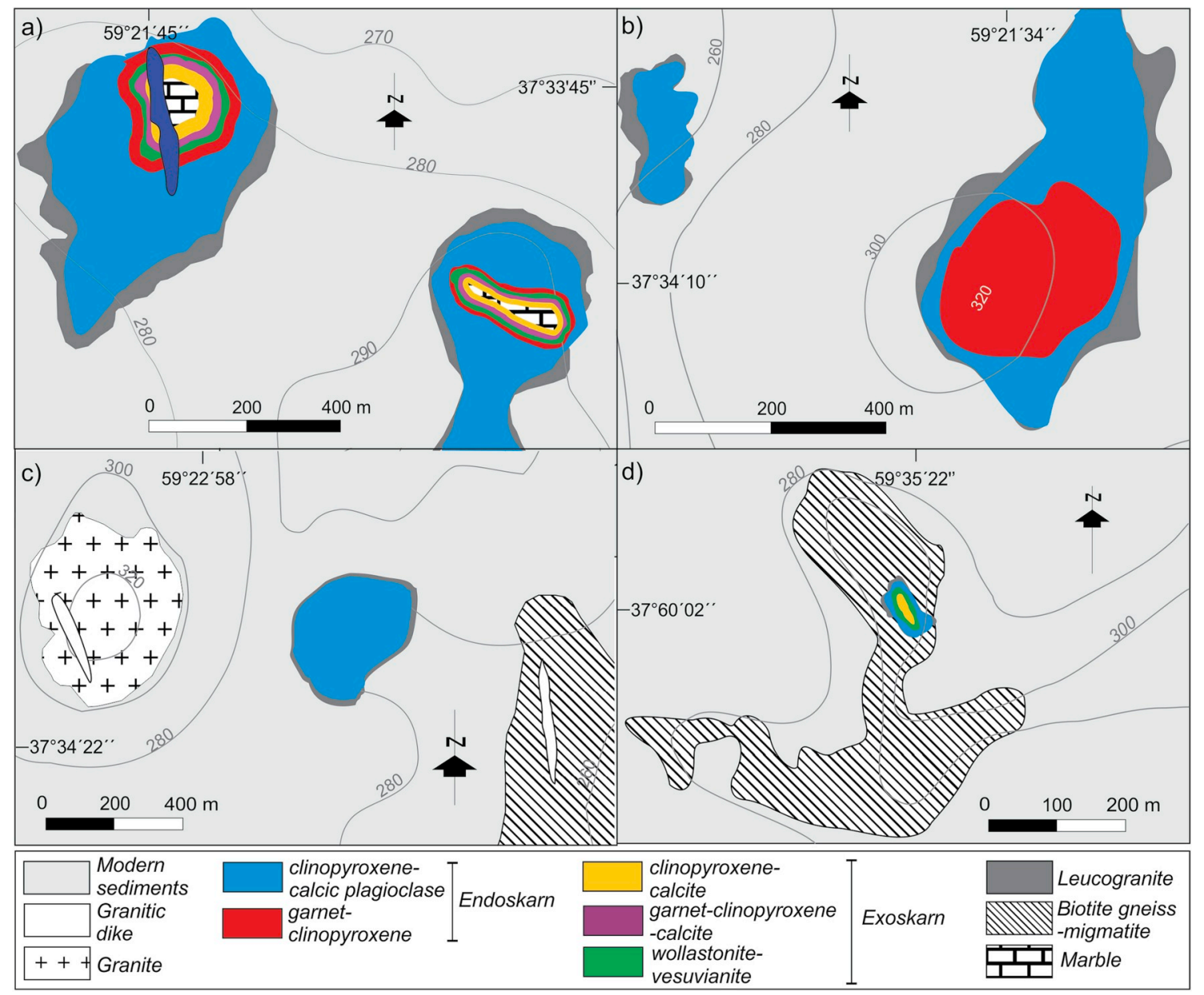

Fig. 3. Schematic geological map showing the skarn outcrops and the distribution of the paragenesis of each defined mineral zone. a) San Miguel north-western sector (NWS) and north-eastern sector (NES), b) San Miguel southern sector (SS), c) La Concordia farm and d) Siempre Verde farm.

Isotech SIRA-II dual inlet mass spectrometer, equipped with cold finger to analyse small samples and a multiple admission system. Both internal and international reference standards were run to check accuracy and precision. The isotopic ratios are expressed using the $\delta \%$ notation, with an analytical error of $\pm 0.2 \%$. $\delta^{18} \mathrm{O}$ results are given in relation to the Standard Mean Ocean Water (V-SMOW).

\section{Mineral zones petrography}

\subsection{Exoskarn}

\subsubsection{Wollastonite-vesuvianite}

Developed mainly at the marble-leucogranite contact, wollastonitevesuvianite is represented by the mineral paragenesis: wollastonite + vesuvianite \pm clinopyroxene (Fig. $4 \mathrm{a}$ and b). Wollastonite is the most abundant mineral, is fibrous and grows in radiated form (Fig. 4a). Vesuvianite crystals are scarce but large, have a greenish to brown colour and a poorly developed prismatic habit. With an analyzer it presents a low interference colour (Fig. 4c). The clinopyroxene (10-20\% of the total volume) is dark-green with prismatic habit and is located randomly between the wollastonite fibers (Fig. 4b and c). In addition, few quartz and calcite crystals were recognised in interstitial sectors (Fig. 4b).

\subsubsection{Garnet-clinopyroxene}

It is composed of: garnet, clinopyroxene, calcite and quartz. The garnet is reddish to brown, presents several opaque minerals and forms aggregates (Fig. 4d). The clinopyroxene crystals are dark green in colour, have a maximum size of $2 \mathrm{~mm}$ and are found among the garnet crystals (Fig. 4c and d) and disseminated in the calcite. The calcite is grey due to the presence of solid dark-grey inclusions. The scarce quartz crystals are also grey and are hosted within the aggregates of garnet crystals (Fig. 4a and b) and in small veinlets.

\subsubsection{Clinopyroxene}

This zone is constituted almost by coarse-grain to medium size calcite crystals $(5-10 \mathrm{~mm})$ with opaque inclusions, similar characteristics as the calcite from the garnet-clinopyroxene zone (Fig. $4 \mathrm{~g}$, $\mathrm{h}$ and i). The clinopyroxene constitutes about $20 \%$ of the zone, has dark green to light green colour, in general is translucent to slightly transparent, and has a grain size in the order of $2-4 \mathrm{~mm}$ (Fig. $4 \mathrm{~h}$ and i).

\subsection{Endoskarn}

\subsubsection{Garnet-clinopyroxene}

The recognised association in this zone is: garnet + clinopyroxene + quartz (Fig. $4 \mathrm{j}$ and $\mathrm{k}$ ). The more abundant minerals are garnet and clinopyroxene, which exhibit great development in size $(>1 \mathrm{~cm}$ in some cases). The garnet has a reddish-brown colour and develops several centimetres in diameter; in some sectors it forms aggregates with "spherical" morphologies composed of small euhehedral crystals, some with anisotropic edges (Fig. $4 \mathrm{k}$ and i). Clinopyroxene has, in general, a prismatic habit and a light green colour (Fig. 4j). The quartz is abundant and is located around the garnet and the clinopyroxene crystals (Fig. 4l), forming part of the modified leucogranite by the metasomatic processes. 

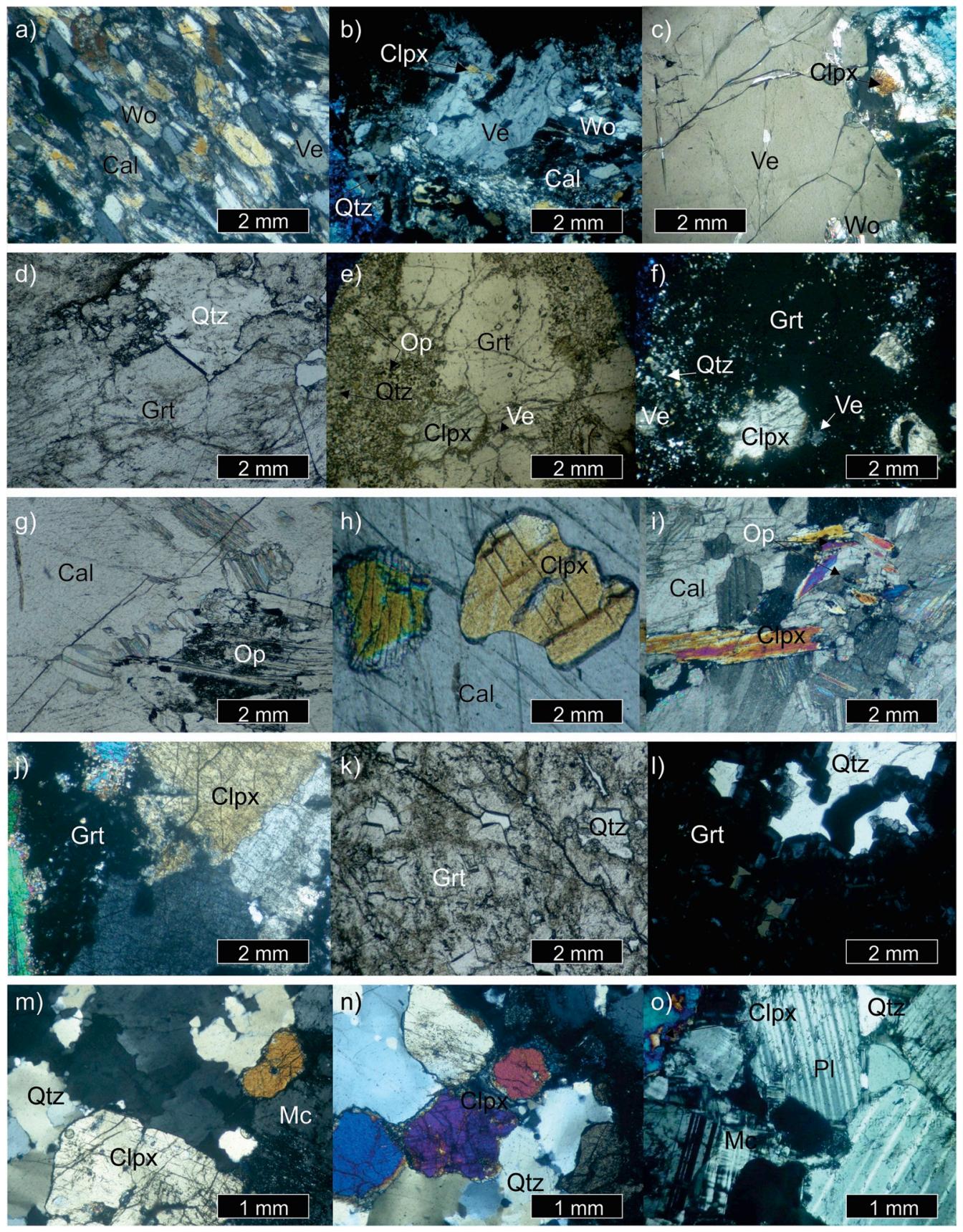

Fig. 4. Exoskarn zones microphotographic detail: a, b, c) Vesuvianite-wollastonite zone minerals aspect (with analyzer). d, e, f) Garnet-clinopyroxene zone mineralogy (only f) with analyzer). g, h, i) Clinopyroxene zone. Note the opaque accumulation in picture g) without analyzer. Endoskarn zones microprotographic detail: j, k, l) Garnet-clinopyroxene zone, k) and l) pictures show the garnet aggregates aspect without and with analyzer, respectively. m, n, o) Clinopyroxene-calcic plagioclase zone.

\subsubsection{Clinopyroxeno-calcic plagioclase}

This zone comprises the more distal sector of the skarn (with respect to the marble-leucogratine contact). It has a granite igneous rock appearance (Fig. 4m, n, o) with a granular texture composed mostly by potassium feldspar, plagioclase and quartz. With this mineralogy, clinopyroxene crystals and paseudomorphic textures of plagioclase replacement potassic feldspar are observed (Fig. $4 \mathrm{n}$ and o). Clinopyroxene is greenish, scarce and has a homogeneous distribution. Its abundance decreases until it disappears in the furthest sector from the garnetclinopyroxene zone contact. Plagioclase has a wide compositional range between $\mathrm{An}_{40}$ and $\mathrm{An}_{60}$ (Lajoinie et al., 2013), where the most calcic crystals are developed from the replacement of potassium feldspar crystals (Fig. 4o).

\section{Chemical composition of the minerals}

Vesuvianite, garnet and clinopyroxene crystals were studied. Chemical analysis made it possible to define a general formula $(\mathrm{Na}, \mathrm{K}, \mathrm{Ca}, \mathrm{Ba})_{19}(\mathrm{Mn}, \mathrm{Ni}, \mathrm{Mg}, \mathrm{Fe}, \mathrm{Cr}, \mathrm{Al}, \mathrm{Ti})_{13}\left(\mathrm{PO}_{4}\right)_{0.2} \mathrm{Si}_{18} \mathrm{O}_{68}(\mathrm{~F}, \mathrm{Cl}, \mathrm{OH})_{10}$ for vesuvianite (Table 1), following the mineral formula proposed by Groat et al. (1992). The analyses show the expected values for this mineral but it is remarkable the high $\mathrm{F}$ tenor of $0.55 \%$ and the absence of B. Besides, all the crystals have a moderate content of $\mathrm{FeO}(5.46 \%)$. Exoskarn garnet shows a composition which varies between 
Table 1

Vesuvianite average chemical composition. Obtained from EDAX analysis.

\begin{tabular}{|c|c|c|c|c|c|}
\hline Oxide & $\% \mathrm{wt}$ & Oxide & $\%$ wt & Oxide & $\%$ wt \\
\hline $\mathrm{SiO}_{2}$ & 36.85 & $\mathrm{MnO}$ & 0.09 & $\mathrm{CaO}$ & 36.86 \\
\hline $\mathrm{TiO}_{2}$ & 0.30 & $\mathrm{MgO}$ & 0.90 & $\mathrm{BaO}$ & 0.09 \\
\hline $\mathrm{Al}_{2} \mathrm{O}_{3}$ & 18.60 & $\mathrm{NiO}$ & 0.02 & $\mathrm{P}_{2} \mathrm{O}_{5}$ & 0.20 \\
\hline $\mathrm{Cr}_{2} \mathrm{O}_{3}$ & 0.02 & $\mathrm{~K}_{2} \mathrm{O}$ & 0.03 & $\mathrm{~F}$ & 0.55 \\
\hline $\mathrm{FeO}$ & 5.46 & $\mathrm{Na}_{2} \mathrm{O}$ & 0.01 & $\mathrm{Cl}$ & 0.13 \\
\hline
\end{tabular}

All the Fe was considered as FeO. Chemical formula was calculated following Groat et al. (1992).

Table 2

Representative microprobe analices from endo and exoskarn garnet crystals.

\begin{tabular}{|c|c|c|c|c|c|c|c|c|c|c|c|c|}
\hline \multirow[t]{2}{*}{ Oxide } & \multicolumn{6}{|c|}{ Endoskarn } & \multicolumn{6}{|c|}{ Exoskarn } \\
\hline & $\mathrm{P} 1$ & $\mathrm{P} 2$ & P3 & P4 & P5 & P6 & $\mathrm{P} 1$ & P2 & P3 & P4 & P5 & P6 \\
\hline $\mathrm{SiO}_{2}$ & 39.85 & 39.97 & 39.57 & 39.90 & 39.46 & 40.02 & 40.26 & 38.95 & 38.74 & 38.36 & 39.51 & 39.75 \\
\hline $\mathrm{P}_{2} \mathrm{O}_{5}$ & 0.24 & 0.37 & 0.34 & 0.37 & 0.32 & 0.38 & 0.24 & 0.36 & 0.32 & 0.35 & 0.34 & 0.37 \\
\hline $\mathrm{TiO}_{2}$ & 0.00 & 0.20 & 0.18 & 0.26 & 0.22 & 0.24 & 0.00 & 0.51 & 0.62 & 0.57 & 0.26 & 0.22 \\
\hline $\mathrm{Al}_{2} \mathrm{O}_{3}$ & 32.22 & 20.89 & 20.63 & 20.64 & 20.72 & 20.78 & 30.71 & 20.51 & 19.42 & 18.14 & 20.82 & 20.92 \\
\hline $\mathrm{Cr}_{2} \mathrm{O}_{3}$ & 0.00 & 0.00 & 0.00 & 0.00 & 0.00 & 0.01 & 0.03 & 0.04 & 0.01 & 0.03 & 0.00 & 0.00 \\
\hline $\mathrm{FeO}_{\mathrm{T}}$ & 1.23 & 2.40 & 2.37 & 2.39 & 2.29 & 2.53 & 3.11 & 3.21 & 5.36 & 8.11 & 2.44 & 2.33 \\
\hline $\mathrm{Feo}^{\mathrm{a}}$ & 1.23 & 1.41 & 0.99 & 0.65 & 1.09 & 1.84 & 3.11 & 0.23 & 2.01 & 3.16 & 0.99 & 0.67 \\
\hline $\mathrm{Fe}_{2} \mathrm{O}_{3}{ }^{\mathrm{a}}$ & 0.00 & 1.09 & 1.53 & 1.93 & 1.34 & 0.76 & 0.00 & 3.32 & 3.73 & 5.49 & 1.62 & 1.85 \\
\hline $\mathrm{MnO}$ & 0.03 & 0.00 & 0.08 & 0.00 & 0.05 & 0.03 & 0.00 & 0.09 & 0.07 & 0.14 & 0.03 & 0.02 \\
\hline $\mathrm{MgO}$ & 0.01 & 0.17 & 0.18 & 0.17 & 0.19 & 0.18 & 0.01 & 0.08 & 0.04 & 0.06 & 0.19 & 0.17 \\
\hline $\mathrm{NiO}$ & 0.05 & 0.00 & 0.02 & 0.00 & 0.00 & 0.00 & 0.00 & 0.00 & 0.01 & 0.00 & 0.02 & 0.04 \\
\hline $\mathrm{CaO}$ & 24.48 & 36.23 & 35.93 & 36.10 & 35.91 & 36.02 & 24.28 & 35.80 & 34.77 & 33.21 & 36.17 & 36.59 \\
\hline $\mathrm{Na}_{2} \mathrm{O}$ & 0.03 & 0.02 & 0.03 & 0.04 & 0.04 & 0.00 & 0.03 & 0.02 & 0.02 & 0.06 & 0.02 & 0.01 \\
\hline $\mathrm{K}_{2} \mathrm{O}$ & 0.03 & 0.01 & 0.00 & 0.01 & 0.01 & 0.02 & 0.01 & 0.00 & 0.01 & 0.01 & 0.00 & 0.00 \\
\hline$\Sigma$ & 99.39 & 102.78 & 101.86 & 102.48 & 101.65 & 102.82 & 101.80 & 103.12 & 105.14 & 107.70 & 102.41 & 102.94 \\
\hline cations & \multicolumn{12}{|c|}{12 oxygens } \\
\hline $\mathrm{Si}$ & 3.03 & 3.02 & 3.01 & 3.02 & 3.01 & 3.02 & 3.06 & 2.97 & 2.98 & 2.98 & 2.99 & 2.99 \\
\hline $\mathrm{P}^{+5}$ & 0.01 & 0.01 & 0.01 & 0.01 & 0.01 & 0.01 & 0.01 & 0.01 & 0.01 & 0.01 & 0.01 & 0.01 \\
\hline $\mathrm{Al}$ & 0.00 & 0.00 & 0.00 & 0.00 & 0.00 & 0.00 & & 0.02 & 0.01 & 0.01 & 0.00 & 0.00 \\
\hline$\Sigma$ & 3.03 & 3.03 & 3.02 & 3.03 & 3.02 & 3.04 & 3.07 & 3.00 & 3.00 & 3.00 & 3.00 & 3.01 \\
\hline $\mathrm{Al}$ & 2.80 & 1.86 & 1.85 & 1.84 & 1.86 & 1.85 & 2.71 & 1.82 & 1.74 & 1.65 & 1.86 & 1.86 \\
\hline $\mathrm{Fe}^{3+}$ & 0.00 & 0.06 & 0.09 & 0.11 & 0.08 & 0.04 & 0.00 & 0.19 & 0.22 & 0.33 & 0.09 & 0.11 \\
\hline $\mathrm{Ti}$ & 0.00 & 0.01 & 0.01 & 0.01 & 0.01 & 0.01 & 0.00 & 0.03 & 0.04 & 0.03 & 0.02 & 0.01 \\
\hline $\mathrm{Cr}$ & 0.00 & 0.00 & 0.00 & 0.00 & 0.00 & 0.00 & 0.00 & 0.00 & 0.00 & 0.00 & 0.00 & 0.00 \\
\hline $\mathrm{Mg}$ & 0.00 & 0.02 & 0.02 & 0.02 & 0.02 & 0.02 & 0.00 & 0.01 & 0.00 & 0.01 & 0.02 & 0.02 \\
\hline $\mathrm{Fe}^{2+}$ & 0.08 & 0.09 & 0.06 & 0.04 & 0.07 & 0.12 & 0.19 & 0.01 & 0.13 & 0.21 & 0.06 & 0.04 \\
\hline $\mathrm{Mn}$ & 0.00 & 0.00 & 0.00 & 0.00 & 0.00 & 0.00 & 0.00 & 0.01 & 0.00 & 0.01 & 0.00 & 0.00 \\
\hline $\mathrm{Ni}$ & 0.00 & 0.00 & 0.00 & 0.00 & 0.00 & 0.00 & 0.00 & 0.00 & 0.00 & 0.00 & 0.00 & 0.00 \\
\hline $\mathrm{Ca}$ & 1.99 & 2.93 & 2.93 & 2.93 & 2.93 & 2.92 & 1.98 & 2.92 & 2.86 & 2.76 & 2.94 & 2.95 \\
\hline $\mathrm{Na}$ & 0.00 & 0.00 & 0.00 & 0.01 & 0.01 & 0.00 & 0.00 & 0.00 & 0.00 & 0.01 & 0.00 & 0.00 \\
\hline $\mathrm{K}$ & 0.00 & 0.00 & 0.00 & 0.00 & 0.00 & 0.00 & 0.00 & 0.00 & 0.00 & 0.00 & 0.00 & 0.00 \\
\hline suma & 4.88 & 4.97 & 4.98 & 4.96 & 4.98 & 4.96 & 4.88 & 5.00 & 5.00 & 5.01 & 5.00 & 5.00 \\
\hline$\Sigma_{\text {Total }}$ & 7.91 & 8.00 & 8.00 & 7.99 & 8.00 & 8.00 & 7.95 & 8.00 & 8.00 & 8.01 & 8.00 & 8.00 \\
\hline \multicolumn{13}{|c|}{ Molecular \% } \\
\hline Prp & 0.03 & 0.63 & 0.67 & 0.64 & 0.70 & 0.68 & 0.06 & 0.31 & 0.16 & 0.24 & 0.70 & 0.63 \\
\hline Alm & 3.64 & 2.94 & 2.10 & 1.39 & 2.31 & 3.82 & 8.79 & 0.50 & 4.33 & 6.97 & 2.08 & 1.41 \\
\hline Sps & 0.10 & 0.01 & 0.16 & 0.00 & 0.10 & 0.07 & 0.00 & 0.19 & 0.16 & 0.31 & 0.07 & 0.05 \\
\hline Grs & 96.22 & 93.18 & 92.52 & 92.30 & 92.93 & 93.11 & 91.09 & 89.38 & 84.25 & 75.93 & 92.42 & 92.55 \\
\hline Adr & 0.00 & 3.24 & 4.55 & 5.66 & 3.97 & 2.29 & 0.00 & 9.51 & 11.08 & 16.46 & 4.74 & 5.35 \\
\hline Uvt & 0.01 & 0.00 & 0.00 & 0.01 & 0.00 & 0.03 & 0.06 & 0.11 & 0.02 & 0.09 & 0.00 & 0.00 \\
\hline$\Sigma$ & 100.0 & 100.0 & 100.0 & 100.0 & 100.0 & 100.0 & 100.0 & 100.0 & 100.0 & 100.0 & 100.0 & 100.0 \\
\hline
\end{tabular}

a Calculated following Droop (1987).

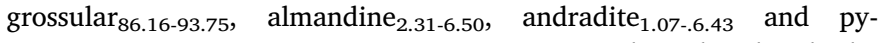
rope + spessartine + uvarovite $<0.91 \%$. On the other hand, the composition of the garnet in the endoskarn fluctuates between grossular $_{93.06-93.92}$, almandine al.78-4.25 $_{\text {and andradite }}{ }_{1.63-3.36}$ while the other components (pyrope + spessartine + uvarovite) are not higher than $0.85 \%$ (Table 2).

Exoskarn clinopyroxene crystals have a diopside ${ }_{62.32-71.23}$, hedenbergite $_{28.71-37.43}$ and johansenite $e_{0.06-0.25}$ composition, and those of the endoskarn a clinopyroxene diopside ${ }_{79.70-86.19}$, hedenbergite ${ }_{13.70-}$ 20.09 and johansenite $0.11-0.25$ composition (Table 3).

\section{Fluid inclusion characterisation}

\subsection{Fluid inclusions petrography}

FI analyses were performed on minerals of different skarn zones. All the studied inclusions are $>10 \mu \mathrm{m}$ in size and contain two or more phases. Six types of primary FI were initially identified and classified according to their morphology and number of phases, as shown in Fig. 5: a) type i are irregular two-phased, b) type ii are irregular threephased, c) type iii are ovoid two-phased, d) type iv are regular two- 
Table 3

Representative electron microprobe analyses of endo and exoskarn clinopyroxene crystals.

\begin{tabular}{|c|c|c|c|c|c|c|c|c|c|c|c|c|}
\hline \multirow[t]{2}{*}{ Oxide } & \multicolumn{6}{|c|}{ Endoskarn } & \multicolumn{6}{|c|}{ Exoskarn } \\
\hline & $\mathrm{P} 1$ & $\mathrm{P} 2$ & P3 & P4 & P5 & P6 & P1 & P2 & P3 & P4 & P5 & P6 \\
\hline $\mathrm{SiO}_{2}$ & 53.35 & 53.83 & 53.76 & 54.07 & 53.81 & 53.89 & 52.60 & 52.75 & 52.05 & 52.63 & 53.08 & 52.66 \\
\hline $\mathrm{P}_{2} \mathrm{O}_{5}$ & 0.17 & 0.17 & 0.15 & 0.12 & 0.13 & 0.16 & 0.11 & 0.15 & 0.17 & 0.14 & 0.21 & 0.16 \\
\hline $\mathrm{TiO}_{2}$ & 0.03 & 0.04 & 0.00 & 0.01 & 0.03 & 0.05 & 0.00 & 0.00 & 0.07 & 0.00 & 0.02 & 0.00 \\
\hline $\mathrm{Al}_{2} \mathrm{O}_{3}$ & 0.48 & 0.66 & 0.64 & 0.68 & 0.67 & 0.66 & 0.06 & 0.24 & 0.31 & 0.63 & 0.17 & 0.60 \\
\hline $\mathrm{Cr}_{2} \mathrm{O}_{3}$ & 0.00 & 0.00 & 0.00 & 0.04 & 0.00 & 0.00 & 0.00 & 0.01 & 0.00 & 0.00 & 0.03 & 0.01 \\
\hline $\mathrm{FeO}_{\mathrm{T}}$ & 6.37 & 5.43 & 4.90 & 4.33 & 4.59 & 4.37 & 9.08 & 9.95 & 11.61 & 10.14 & 9.63 & 10.51 \\
\hline $\mathrm{FeO}^{\mathrm{a}}$ & 4.92 & 4.38 & 3.24 & 3.44 & 2.94 & 2.84 & 7.97 & 8.65 & 10.93 & 8.65 & 8.79 & 9.47 \\
\hline $\mathrm{Fe}_{2} \mathrm{O}_{3}{ }^{\mathrm{a}}$ & 1.62 & 1.16 & 1.84 & 0.98 & 1.84 & 1.70 & 1.24 & 1.45 & 0.76 & 1.66 & 0.93 & 1.15 \\
\hline $\mathrm{MnO}$ & 0.07 & 0.08 & 0.05 & 0.03 & 0.05 & 0.03 & 0.02 & 0.08 & 0.08 & 0.00 & 0.04 & 0.09 \\
\hline $\mathrm{MgO}$ & 14.24 & 14.66 & 15.14 & 15.33 & 15.30 & 15.20 & 12.68 & 12.25 & 10.89 & 11.63 & 12.39 & 11.50 \\
\hline $\mathrm{NiO}$ & 0.02 & 0.02 & 0.10 & 0.03 & 0.00 & 0.00 & 0.00 & 0.02 & 0.06 & 0.00 & 0.01 & 0.00 \\
\hline $\mathrm{CaO}$ & 25.71 & 25.72 & 25.92 & 25.45 & 25.75 & 26.15 & 25.65 & 25.61 & 24.78 & 25.76 & 25.61 & 25.20 \\
\hline $\mathrm{Na}_{2} \mathrm{O}$ & 0.18 & 0.23 & 0.21 & 0.28 & 0.26 & 0.25 & 0.05 & 0.08 & 0.09 & 0.18 & 0.08 & 0.18 \\
\hline $\mathrm{K}_{2} \mathrm{O}$ & 0.05 & 0.01 & 0.02 & 0.05 & 0.08 & 0.04 & 0.02 & 0.03 & 0.01 & 0.01 & 0.03 & 0.02 \\
\hline$\Sigma$ & 100.8 & 100.9 & 101.05 & 100.52 & 100.85 & 100.98 & 100.40 & 101.32 & 100.20 & 101.28 & 101.38 & 101.06 \\
\hline cations & 6 oxygen & & & & & & & & & & & \\
\hline $\mathrm{Si}$ & 1.97 & 1.97 & 1.96 & 1.98 & 1.96 & 1.97 & 1.97 & 1.96 & 1.98 & 1.96 & 1.97 & 1.97 \\
\hline $\mathrm{P}^{+5}$ & 0.00 & 0.00 & 0.00 & 0.00 & 0.00 & 0.00 & 0.00 & 0.00 & 0.00 & 0.00 & 0.00 & 0.00 \\
\hline $\mathrm{Al}$ & 0.02 & 0.02 & 0.03 & 0.02 & 0.03 & 0.03 & 0.00 & 0.01 & 0.01 & 0.03 & 0.01 & 0.02 \\
\hline $\mathrm{Fe}^{+3}$ & 0.01 & 0.00 & 0.01 & 0.00 & 0.01 & 0.01 & 0.03 & 0.02 & 0.01 & 0.01 & 0.02 & 0.00 \\
\hline$\Sigma$ & 2.00 & 2.00 & 2.00 & 2.00 & 2.00 & 2.00 & 2.00 & 2.00 & 2.00 & 2.00 & 2.00 & 2.00 \\
\hline $\mathrm{Al}$ & 0.00 & 0.01 & 0.00 & 0.01 & 0.00 & 0.00 & 0.00 & 0.00 & 0.00 & 0.00 & 0.00 & 0.00 \\
\hline $\mathrm{Fe}^{3+}$ & 0.04 & 0.03 & 0.05 & 0.03 & 0.05 & 0.04 & 0.03 & 0.04 & 0.02 & 0.05 & 0.02 & 0.03 \\
\hline $\mathrm{Ti}$ & 0.00 & 0.00 & 0.00 & 0.00 & 0.00 & 0.00 & 0.00 & 0.00 & 0.00 & 0.00 & 0.00 & 0.00 \\
\hline $\mathrm{Cr}$ & 0.00 & 0.00 & 0.00 & 0.00 & 0.00 & 0.00 & 0.00 & 0.00 & 0.00 & 0.00 & 0.00 & 0.00 \\
\hline $\mathrm{Mg}$ & 0.78 & 0.80 & 0.82 & 0.83 & 0.83 & 0.83 & 0.71 & 0.68 & 0.62 & 0.65 & 0.69 & 0.64 \\
\hline $\mathrm{Fe}^{2+}$ & 0.14 & 0.13 & 0.09 & 0.10 & 0.09 & 0.08 & 0.23 & 0.25 & 0.34 & 0.27 & 0.26 & 0.29 \\
\hline $\mathrm{Mn}$ & 0.00 & 0.00 & 0.00 & 0.00 & 0.00 & 0.00 & 0.00 & 0.00 & 0.00 & 0.00 & 0.00 & 0.00 \\
\hline $\mathrm{Ni}$ & 0.00 & 0.00 & 0.00 & 0.00 & 0.00 & 0.00 & 0.00 & 0.00 & 0.00 & 0.00 & 0.00 & 0.00 \\
\hline $\mathrm{Ca}$ & 1.01 & 1.01 & 1.01 & 1.00 & 1.01 & 1.02 & 1.03 & 1.02 & 1.01 & 1.03 & 1.02 & 1.01 \\
\hline $\mathrm{Na}$ & 0.01 & 0.02 & 0.01 & 0.02 & 0.02 & 0.02 & 0.00 & 0.01 & 0.01 & 0.01 & 0.01 & 0.01 \\
\hline $\mathrm{K}$ & 0.00 & 0.00 & 0.00 & 0.00 & 0.00 & 0.00 & 0.00 & 0.00 & 0.00 & 0.00 & 0.00 & 0.00 \\
\hline$\Sigma$ & 2.00 & 2.00 & 2.00 & 2.00 & 2.00 & 2.00 & 2.00 & 2.00 & 2.00 & 2.00 & 2.00 & 2.00 \\
\hline$\Sigma_{\text {Total }}$ & 4.00 & 4.00 & 4.00 & 4.00 & 4.00 & 4.00 & 4.00 & 4.00 & 4.00 & 4.00 & 4.00 & 4.00 \\
\hline \multicolumn{13}{|c|}{ Molecular \% } \\
\hline Hd & 20.09 & 17.21 & 15.39 & 13.70 & 14.44 & 13.91 & 28.71 & 31.32 & 37.43 & 32.92 & 30.40 & 33.87 \\
\hline Di & 79.70 & 82.54 & 84.47 & 86.19 & 85.39 & 85.98 & 71.23 & 68.43 & 62.32 & 67.08 & 69.46 & 65.83 \\
\hline Jo & 0.21 & 0.25 & 0.15 & 0.11 & 0.17 & 0.10 & 0.06 & 0.25 & 0.25 & 0.00 & 0.14 & 0.29 \\
\hline$\Sigma$ & 100.00 & 100.00 & 100.00 & 100.00 & 100.00 & 100.00 & 100.00 & 100.00 & 100.00 & 100.00 & 100.00 & 100.00 \\
\hline
\end{tabular}

${ }^{a}$ Calculated following Droop (1987).

phased, e) type $v$ are tabular two-phased and f) type vi are regular multi-phased.

\subsubsection{Exoskarn}

FI in calcite, vesuvianite and grossular crystals were studied. Even though they present numerous primaries of FI, many of them are reduced in size $(<10 \mu \mathrm{m})$ and could not be tested.

Calcite crystals from the exoskarn zones and also from the marble sectors least affected by metasomatism (according to the recorded highest $\delta^{18} \mathrm{O}_{\mathrm{V} \text {-SMow }}$ values of $+17.35 \%$; Lajoinie et al., 2014b) were studied. Although calcite is not an ideal mineral for fluid inclusion studies, its petrographic characterisation allowed scarce FI of small size ( $<10 \mu \mathrm{m}$, not suitable for microthermometric determinations) to be classified as type iii (Fig. 6a). Moreover, the presence of dispersed solid inclusions of opaque minerals up to $2-5 \mu \mathrm{m}$ in size (Fig. $6 \mathrm{~b}$ ) is highlighted (see mineral identification by Raman spectroscopy in section 7.3).

Vesuvianite crystals possess numerous primaries of FI (Fig. 7a) and others associated with small fractures (Fig. 7b) generated during and after the crystal development. These "trends" or trains of fluid inclusions were classified as pseudo secondary (Fig. 7b). Most of them are up to $10 \mu \mathrm{m}$ in size. Type i FI are the least abundant and their content is $\mathrm{L}$ (liquid) $+\mathrm{G}$ (gas), where G > L (Fig. 7c). Most of them are irregular and have a filling degree $\left(\mathrm{F}=\mathrm{V}_{\mathrm{L}} / \mathrm{V}_{\text {Total }}\right) \sim 0.80$. They are randomly distributed along the whole crystal and are from a few $\mu \mathrm{m}$ to $15-30 \mu \mathrm{m}$ in size. Some bubbles are very clear while others are dark brown, which might indicate a change in the chemical composition of the gaseous phase. For this reason, the gas $(\mathrm{G})$ nomenclature was used, which includes $\mathrm{H}_{2} \mathrm{O}$, possibly $\mathrm{CO}_{2}$ or other gaseous components (Fig. 7c). Type ii FI are scarce but large, they are close to $30 \mu \mathrm{m}$ in size and contain $\mathrm{L}+\mathrm{G}+\mathrm{S}$ (Fig. 7d). Types iii and iv FI (Fig. 7e) are the most abundant (Fig. $7 \mathrm{f}$ ) together with type $\mathrm{v}$ (Fig. $7 \mathrm{~g}$ ), all of about $10-20 \mu \mathrm{m}$ in size. $\mathrm{L}$ phase is predominant in these FI types, even though $\mathrm{L} / \mathrm{G}$ ratio reaches up to 1 in some cases. A few large $(\sim 50 \mu \mathrm{m})$ type vi FI (Fig. $7 \mathrm{~h})$ allowed two rhomboidal and colourless crystals (possibly calcite) and two smaller and opaque crystals (Fig. $7 \mathrm{~h}$ ) to be recognised. In addition, an equidimensional crystal and an elongated one, which could not be identified, were found in type vi FI (Fig. 7h). Many of the v and vi FI types, as well as some type i, show multiple "necking down" microstructures (Roedder, 1962; Bodnar, 2003) (Fig. 7a and d), where the initial $\mathrm{L} / \mathrm{G}$ ratio was modified and consequently discarded to perform microthermometric determinations.

Grossular crystals reveal numerous small $(<10 \mu \mathrm{m}$ in size) secondary FI trends, associated with micro fractures that were not considered for microthermometric studies. 


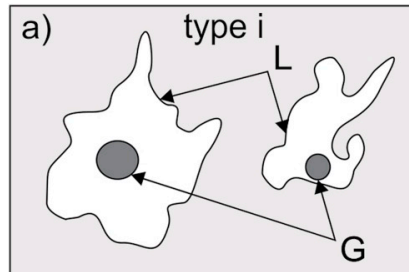

C)

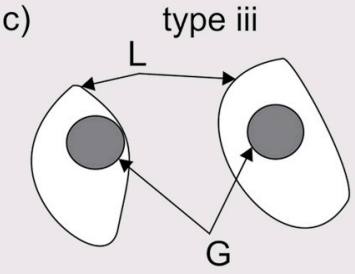

G

e)

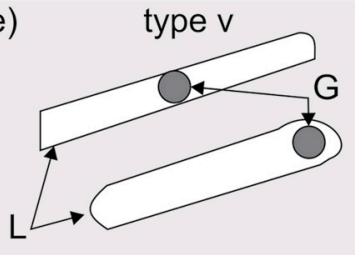

b)

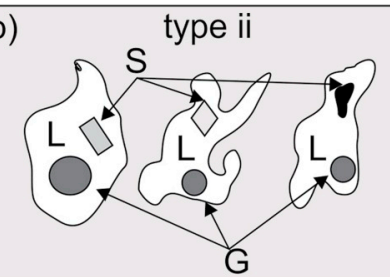

d)

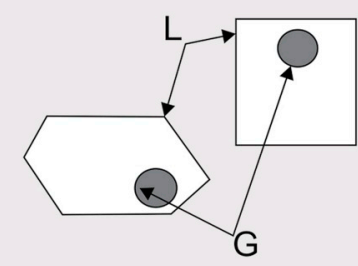

f)

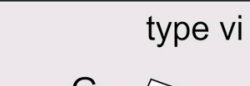
S2

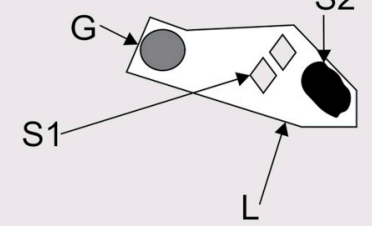

Fig. 5. FI classification based on its morphologies and in the Nash (1976) and Roedder (1984) nomenclatures. a) Type i, irregular biphasic; b) type ii, irregular triphasic; c) type iii, ovoid biphasic; d) type iv, regular biphasic; e) type v, tabular biphasic and f) type vi, regular polyphasic.

\subsubsection{Endoskarn}

Grossular, diopside and interstitial quartz were analysed. Quartz allowed primary and secondary FI to be studied due to its wide stability range, which could register early and late events.

Grossular crystals present numerous secondary FI groups. A few primaries of type i FI (Fig. 8a), iii (Fig. 8b), and iv (Fig. 8c) are bigger than $10 \mu \mathrm{m}$, and have phase relations equal to 0.80 and 0.70 . However, some of them were opened or showed "necking down" and were therefore discarded (Fig. 8d). Scarce type v FI with dark brown bubbles was identified (Fig. 8e). At the same time, three-phased FI (Fig. 8e and f) were recognised, where the solid phases correspond to a cleargreenish mineral (Fig. 8e) and to an irregularly shaped opaque one (Fig. 8f). The diopside has scarce primary FI suitable for microthermometric studies due to its dark green colour and to the abundance of opaque FI. Fluid inclusions are type i (Fig. 9a) and ii with abundant opaque solid material (Fig. 9b), type iv (L + G) of $5-13 \mu \mathrm{m}$ in size (Fig. 9c) and with $\mathrm{F}$ equal to 0.80 predominantly, and abundant type vi FI (S1 + S2 + G + L; Fig. 8d) of small size $(\sim 10 \mu \mathrm{m})$.

The interstitial quartz crystals show scarce and isolated primary FI, of $10-12 \mu \mathrm{m}$ in size (Fig. 10a) and $\mathrm{F}=0.80-0.90$. Most of them are types $\mathrm{i}$ and iii (Fig. 10a, b and c), with fewer types of iv and ii (Fig. 10d). Trends of secondary inclusions have also been identified close to fractures (Fig. 10d).

\subsection{Microthermometry}

FI were initially cooled at $-120^{\circ} \mathrm{C}$ and $-180^{\circ} \mathrm{C}$ to test for the presence of $\mathrm{CO}_{2}$ and $\mathrm{CH}_{4}$, respectively, and to measure the freezing temperature. Then, they were slowly warmed in order to detect the eutectic point temperature (Te), the melting temperature (Tm) and the corresponding liquid-gas homogenisation temperature (Th), according to Roedder (1984) and Shepherd et al. (1985). Although the $\mathrm{CO}_{2}$ is a common component in the gaseous phase of FI in skarn minerals (Velasco, 2004), cooling routines did not show its presence in the system. Furthermore, no changes could be observed below $-120^{\circ} \mathrm{C}$ due to the formation of ice crystals. On the other hand, the daughter crystals (identified in types ii and vi FI) did not reach melting during the heating routine as the FI decrepitated before. Therefore, the Th in theses cases corresponds to the liquid-gas homogenisation. The microthermometric assays results, for the different type of FI in each mineral, are shown in Table 4 and in the Th $v s$. Frequency (Fig. 11) and Salinity vs. Frequency (Fig. 12) histograms. The salinity was obtained from the Tm, following Bodnar (1992).

\subsubsection{Exoskarn: microthermometric results}

A total of 175 measurements of primary FI in vesuvianite crystals were performed. The maximum Th was determined at $335^{\circ} \mathrm{C}$ and most of the measurements were between 240 and $270{ }^{\circ} \mathrm{C}$ (Fig. 11a). The Te varied between -21.5 and $-22.4^{\circ} \mathrm{C}$, indicating a $\mathrm{H}_{2} \mathrm{O}-\mathrm{NaCl}$ / $\mathrm{H}_{2} \mathrm{O}-\mathrm{NaCl}-\mathrm{KCl}$ system (Bodnar, 1992). The Tm indicates a low salinity system between 2.7 and 3.4 eq. wt $\% \mathrm{NaCl}$ (Fig. 12a). Fig. 13 shows a cooling-warming routine of a type iv FI hosted in a vesuvianite crystal. Changes in the phases during the cooling process (Fig. 13a and b) showed the freezing temperature (Tf) (Fig. 13c). During the warming process (Fig. 13d): the Te with the appearance of the first liquid drops (Fig. 13e and f) and the last ice crystal Tm (Fig. 13g) and the Th of the FI at $246{ }^{\circ} \mathrm{C}$ experience disappearance of the gas bubble and homogenisation to liquid (Fig. 13h and i).

\subsubsection{Endoskarn: microthermometric results}

A total of 135 measurements of two-phased and some three-phased FI in grossular crystals were performed. The maximum Th calculated was around $346^{\circ} \mathrm{C}$ while most of the measurements indicated temperatures between the $248-276$ and $304-332{ }^{\circ} \mathrm{C}$ intervals (Fig. 11b). In all cases, the FI homogenised to liquid. The Te between -21.5 and $-24.2^{\circ} \mathrm{C}$ could only be measured in a few FI, which indicates an "aqueous saline system" $\mathrm{NaCl}-\mathrm{KCl}-\mathrm{H}_{2} \mathrm{O}$ (Shepherd et al., 1985). The defined Tm indicates a low salinity, mostly between 2.8 and 3.6 eq. wt

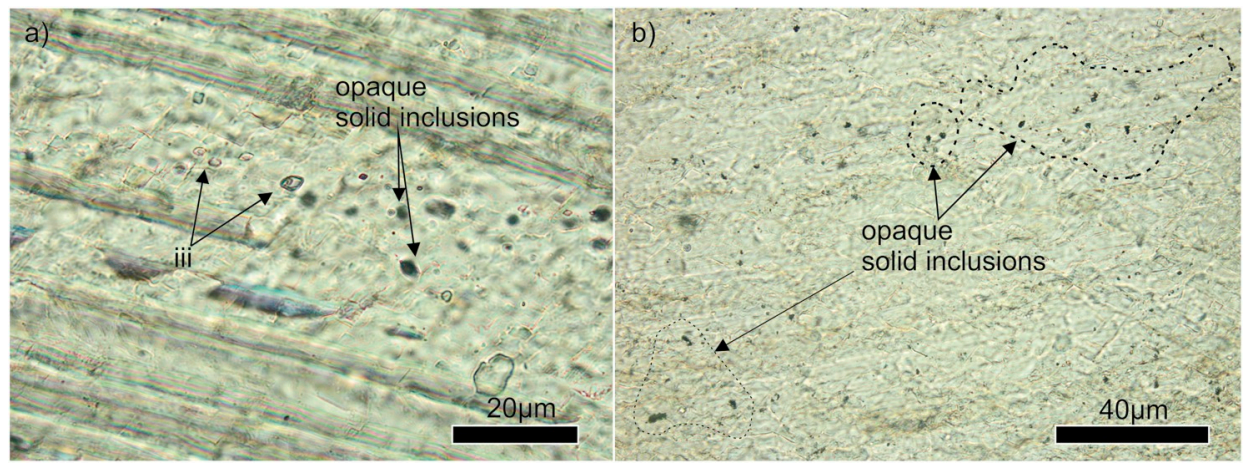

Fig. 6. a) Fluid and solid inclusions in calcite crystal; the FI were classified as type iii. b) Dispersed opaque solid inclusions in calcite crystal. 


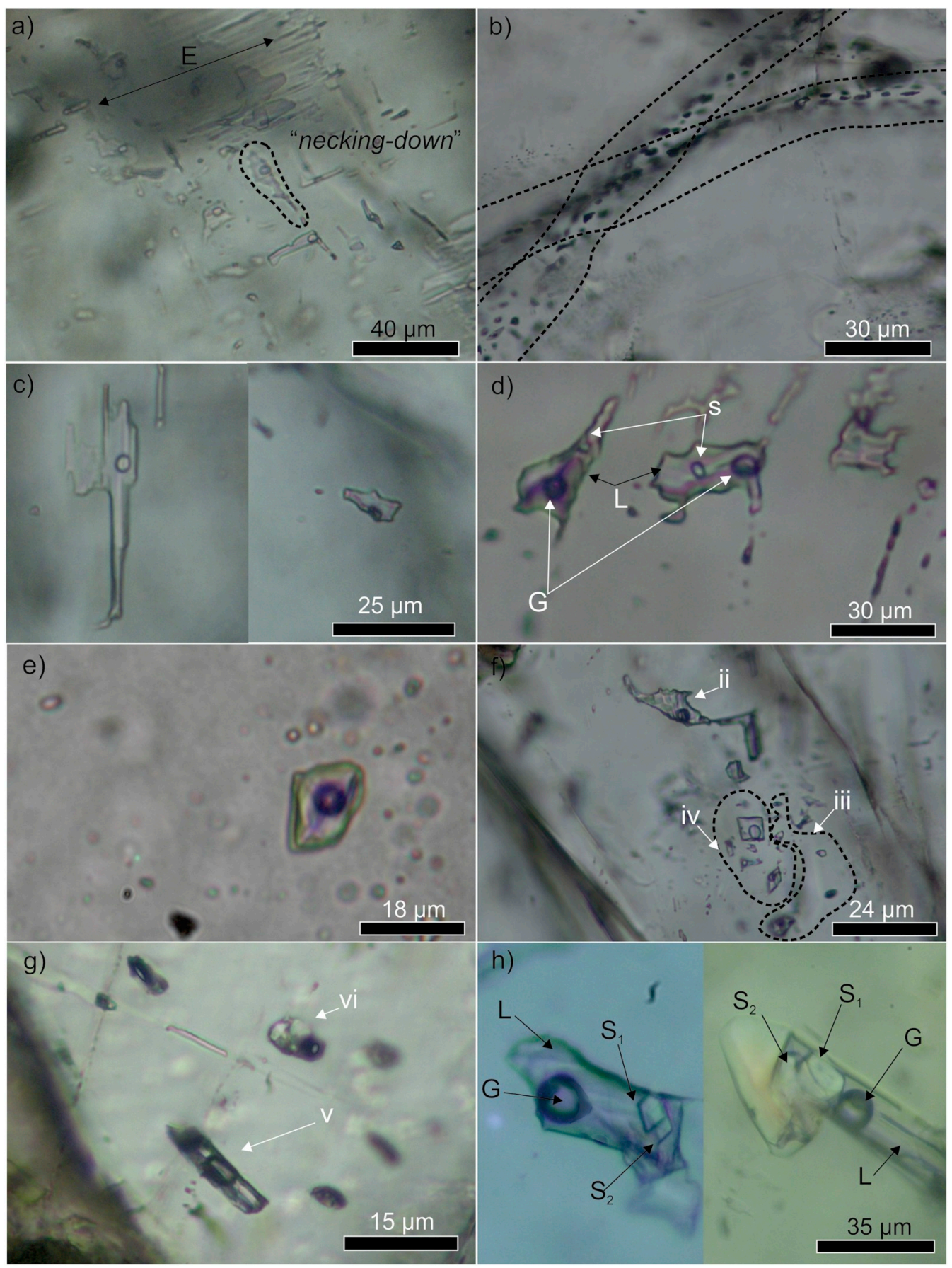

Fig. 7. FI in vesuvianite crystals from the exoskarn. a) Primary FI with parallel-to-elongation growth (E) of the crystal (Goldstein and Reynolds, 1994). "Necking down" FI are highlighted in the figure. b) "Trends" of secondary FI associated with small fractures in the crystal. c) Type i FI with transparent bubbles. d) Type i FI with brown bubble (G) and short greenish prismatic crystal (S). e) Type iii FI with ovoid morphology. f) Groups of types ii, ii and iv FI. g) Tabular-biphasic- type v FI and type vi FI which have a transparent colorless crystal and an opaque crystal. h) Type vi FI trapping rhomboidal, transparent crystals $\left(S_{1}\right.$ and $\left.S_{2}\right)$, on the left side of the figure; another type vi FI with an equidimensional transparent crystal $\left(\mathrm{S}_{1}\right)$ and a transparent elongated crystal $\left(\mathrm{S}_{2}\right)$, in the right side. (For interpretation of the references to colour in this figure legend, the reader is referred to the Web version of this article.)

\% $\mathrm{NaCl}$ (Fig. 12b). Three-phased FI (with opaque solids) showed similar liquid-gas homogenisation temperatures and also similar salinity values to the previous ones (Table 2) decrepitated before dissolution of the solid phase. Primary FI $(\mathrm{N}=117)$ were measured in diopside crystals. A maximum Th of $328^{\circ} \mathrm{C}$ was obtained while most of the measurements were in the $246-286^{\circ} \mathrm{C}$ range (Fig. $\left.11 \mathrm{c}\right)$. The Te $\left(-21.1 /-21.8^{\circ} \mathrm{C}\right)$ indicated a $\mathrm{H}_{2} \mathrm{O}-\mathrm{NaCl}$ system (Shepherd et al., 1985) of low salinity, mostly between 3.0 and 3.7 eq. wt $\% \mathrm{NaCl}$, according to the $\mathrm{Tm}$ measurements (Fig. 12c).

Although the primary FI in quartz crystals, adequate for thermometric studies, were scarce $(\mathrm{N}=50)$, it was possible to determine a Th between 241 and $289^{\circ} \mathrm{C}$ (Fig. 11d). The Tm range between -1.8 and $-4.3^{\circ} \mathrm{C}$ indicates low salinity that varies between 1.1 and 4.4 eq. wt $\%$ $\mathrm{NaCl}$; only five measurements point out a salinity of $6.6-7.7$ eq. wt $\%$ $\mathrm{NaCl}$ (Fig. 12d). Te could not be determined in small FI.

\subsection{Raman spectroscopy}

In order to corroborate the presence or absence of $\mathrm{CO}_{2}$ or other gaseous species like $\mathrm{CH}_{4}$, FI from vesuvianite of the exoskarn and grossular, diopside and quartz of the endoskarn were also analysed by Raman spectroscopy (Fig. 14). The composition of the opaque solid inclusions in the calcite crystals of marble was determined.

The spectra obtained were compared with those of reference from the Raman equipment collected by Hurai et al. (2015) and from the international RUFF database (Lafuente et al., 2015).

Raman spectroscopy studies were focused on gaseous and solid phases, previously identified by petrography in different FI types from exo and endoskarn minerals and from the calcite marble.

Well-defined spectra corresponding to vesuvianite and $\mathrm{OH}$ groups were obtained (Fig. 14a); however, no evidence of $\mathrm{CO}_{2}$ was found 

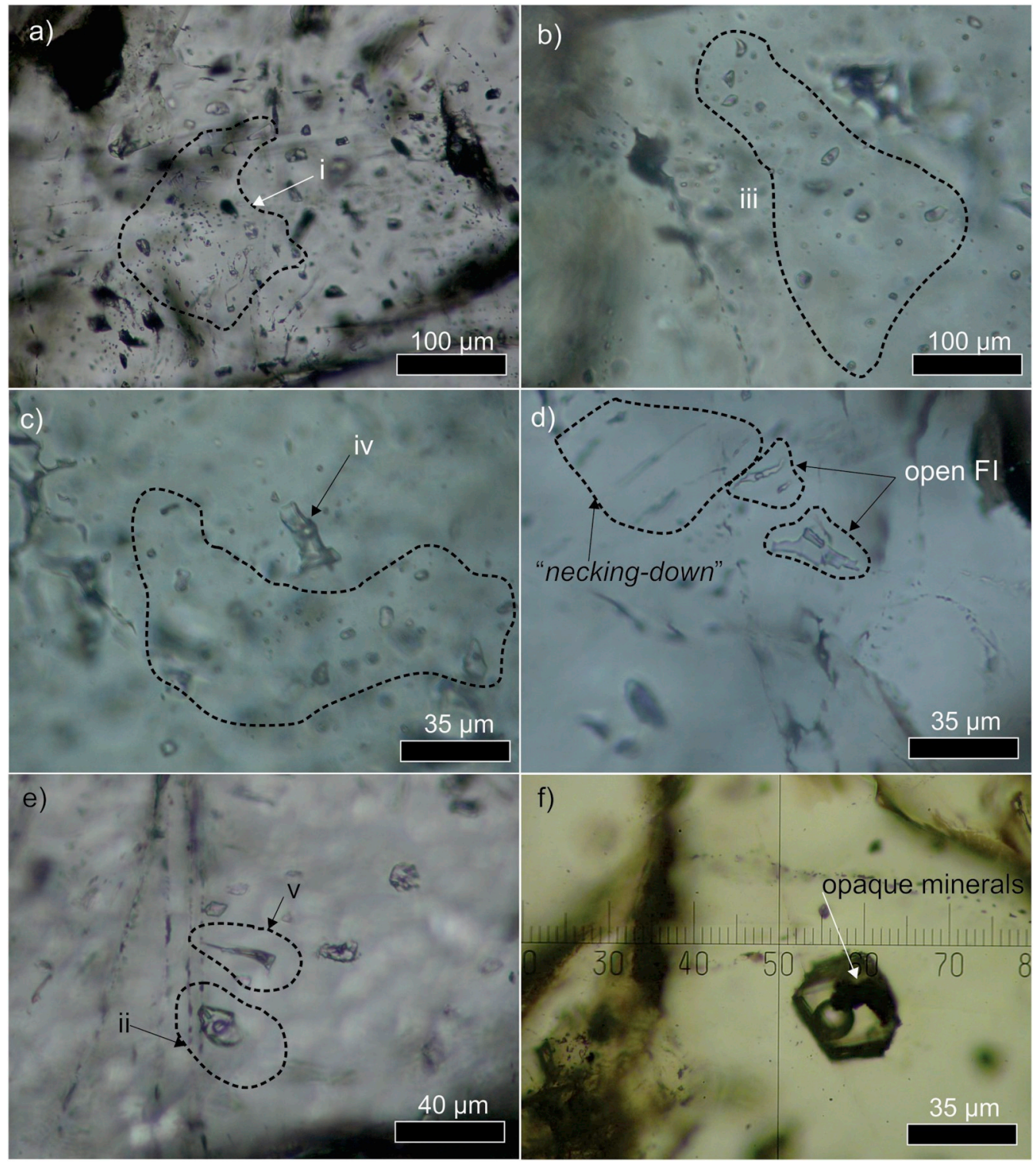

Fig. 8. FI in grossular crystals of the endoskarn. a) Group of type i FI. b) Ovoid and biphasic type iii FI. c) A type iii FI field and a type iv FI of larger size than type iii are highlighted. d) FI with "necking-down" and with open ends. e) Type v and type vi FI. f) Type vi fluid inclusion of big size; the solid crystals could correspond to opaque minerals.

within the FI.

Mg-rich calcite, graphite and methane were observed in some grossular FI (Fig. 14b, c and d). Mg-rich calcites, as well as graphite, are hosted in triphasic FI and its recognition was made through the identification of the following Raman peaks (approximate values given in $\mathrm{cm}^{-1}$ ): 158, 286 and 1092 for Mg-calcite (Figs. 14b), 1361 and 1582 and 2714 for graphite (Fig. 14c). The mentioned values for Mg-calcite are slightly higher than those corresponding to calcite. The cause of the higher values registered in the Raman spectra may be explained considering that $\mathrm{Mg}^{+2}$ has a smaller ionic radius than $\mathrm{Ca}^{+2}(0.072 \mathrm{~nm}$ and $0.10 \mathrm{~nm}$, respectively), and thus $\mathrm{Mg}^{+2}$ enrichment generates a decrease in metal-O interatomic space (Perrin et al., 2016). Methane was identified in some biphasic FI (type iii and iv) due to the Raman peak at $2917.7 \mathrm{~cm}^{-1}$ (Fig. 14d). This peak is slightly displaced towards higher wave numbers than they typically $2917 \mathrm{~cm}^{-1}$ major band, indicating that methane is in low density (Hurai et al., 2015). FI from diopside revealed the presence of graphite crystals with its typical Raman peaks (Fig. 14e). Graphite was also identified in quartz through the analysis of Raman spectra (Fig. 14f).
It should be noted that the large amount of solid inclusions of opaque minerals present in grossular, diopside and quartz correspond to graphite, and none of the analysed samples revealed the presence of $\mathrm{CO}_{2}$ in the FI.

Finally, the measurements of opaque solid inclusions in the calcite from the marble indicated that these solid phases correspond to graphite (Fig. 15).

\subsubsection{Raman spectra of the graphite}

To analyse the graphite crystallinity-degree present in the samples, the Raman spectra of carbonaceous material (CM) was divided into the first $\left(1100-1800 \mathrm{~cm}^{-1}\right)$ and the second $\left(2500-3100 \mathrm{~cm}^{-1}\right)$ order regions (Beyssac et al., 2002) (Fig. 15). In the first-order region three bands are relevant: $G, D_{1}$ and $D_{2}$. The $G$ band is known as the "ordered" band and corresponds to the vibrational mode of the aromatic layers (type $\mathrm{sp}^{2} \mathrm{C}-\mathrm{C}$ ), while the $\mathrm{D}_{1}$ band is assigned to structural defects in the crystal lattice (reflecting a symmetry loss), informally known as the "disordered" band (Beyssac et al., 2002; Hurai et al., 2015; Ruiz and Giraudo de Lucio, 2017). The $D_{2}$ band appears as a shoulder on the 

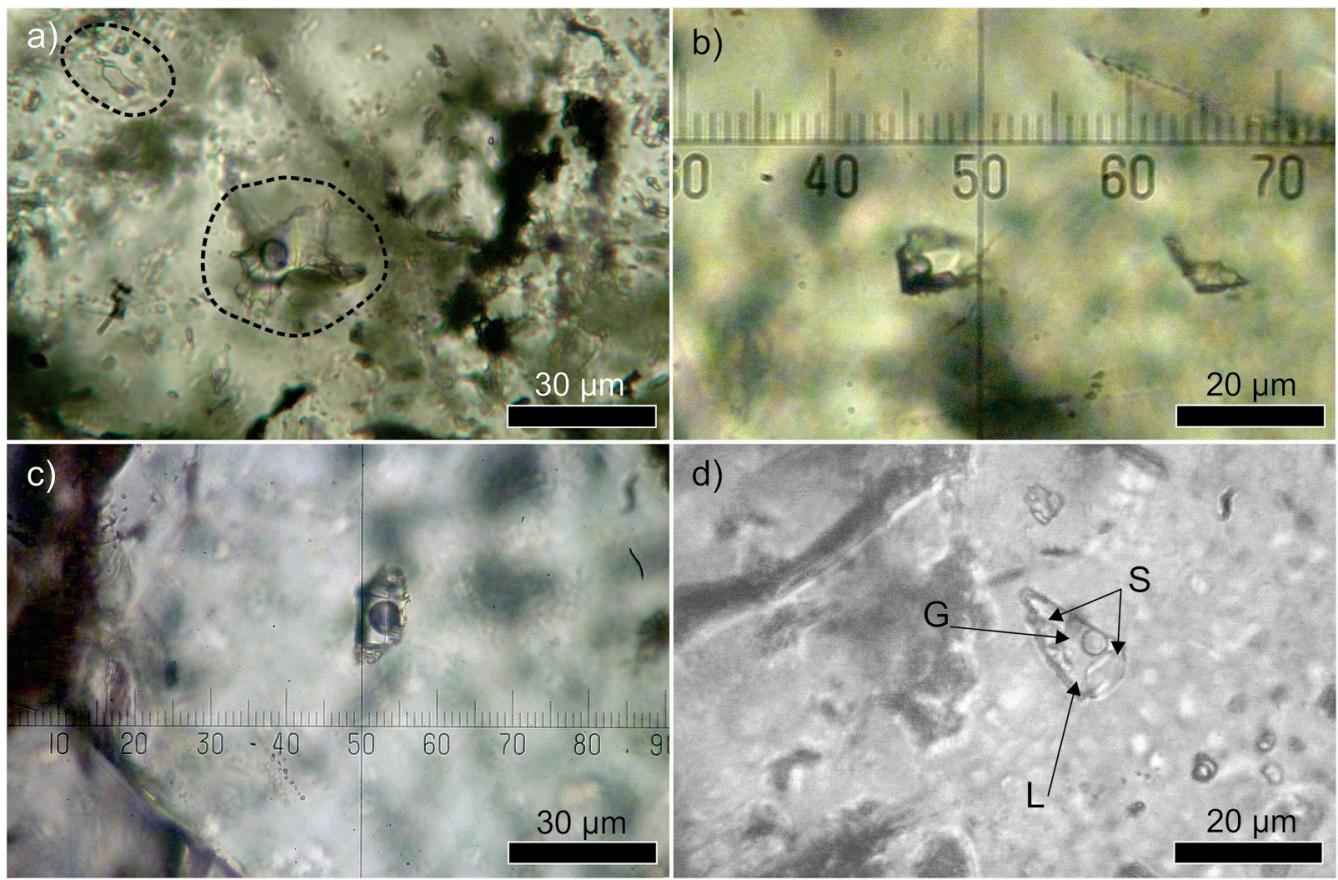

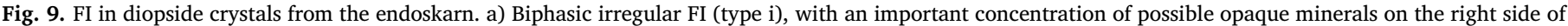
the image. b) Type ii FI. c) Regular biphasic (type iv) FI. d) Regular triphasic (type vi) FI.

right side of $\mathrm{G}$ band in poorly organised $\mathrm{CM}$ and is absent in wellcrystallised graphite (Beyssac et al., 2002). On the other hand, the second-order region corresponds to overtone and combination scattering from the first-region and several bands are identified at $2700\left(\mathrm{~S}_{1}\right)$ and $2900\left(\mathrm{~S}_{2}\right) \mathrm{cm}^{-1}$ (Wopenka and Pasteris, 1993). $\mathrm{S}_{1}$ appears in the last stage of the graphitisation processes and $\mathrm{S}_{2}$ is only present in poorly ordered CM (Tsu et al., 1978).

The graphite hosted in calcite crystals from the skarn external area shows a spectrum with $\mathrm{G}$, which is relatively more narrow and intense, and D bands broad but well defined. The $S_{1}$ band has a medium intensity, while the $S_{2}$ band is absent (Fig. 15). In grossular, the graphite spectrum shows both $G$ and $D$ bands relatively narrow with a moderately strong intensity too; meanwhile the $\mathrm{D}_{2}$ band is weak. The $\mathrm{S}_{1}$ band is well expressed and the second order $S_{2}$ band is only recognised in this set of graphite samples (Fig. 15). Finally, the graphite identified in quartz and diopside samples shows spectra where $\mathrm{G}$ and $\mathrm{D}$ bands have a relatively broad peak with lower intensity and $\mathrm{D}_{2}$ band is absent in the quartz samples. The second order $S_{1}$ band has similar intensity in the

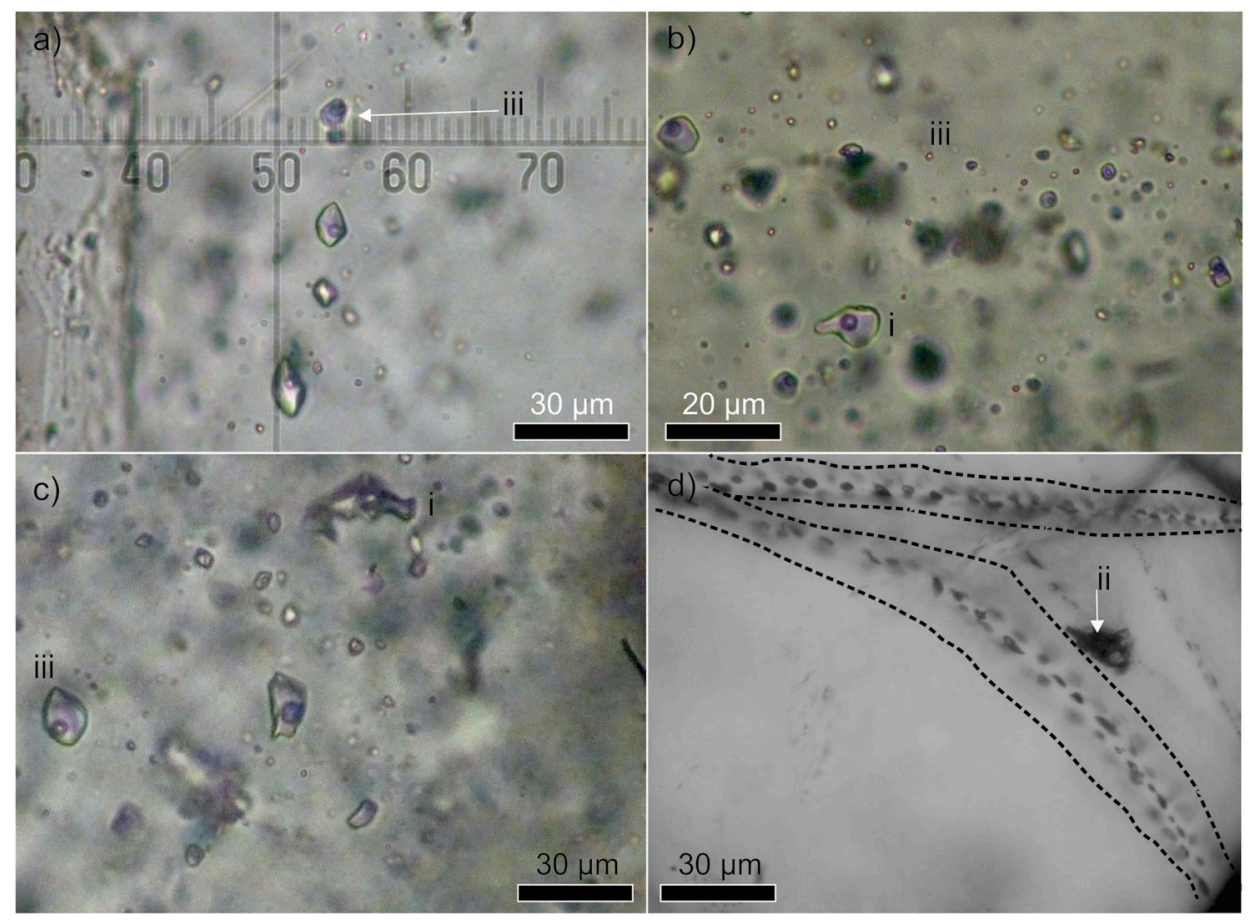

Fig. 10. FI in quartz crystals from the endoskarn. a, b and c) Most common types iii and I FI. d) Type ii FI with an opaque crystal, and two "trends" of secondary FI highlighted in the fields. 
Table 4

Fluid inclusion microthermometric results.

\begin{tabular}{|c|c|c|c|c|c|c|c|}
\hline Zone & Mineral & FI type & $\mathrm{Th}^{\mathrm{a}}$ & $\mathrm{Te}^{\mathrm{a}}$ & $\operatorname{Tm}^{\mathrm{a}}$ & Salinities $^{\mathrm{a}}$ & System \\
\hline \multirow[t]{6}{*}{ Exoskarn } & $\mathrm{Ve}$ & $\mathrm{i}$ & $223-293$ & -21.5 & $-0.8 /-1.8$ & $1.40-3.06$ & $\mathrm{H}_{2} \mathrm{O}-\mathrm{NaCl} / \mathrm{H}_{2} \mathrm{O}-\mathrm{NaCl}-\mathrm{KCl}$ \\
\hline & & ii & $221-245^{* *}$ & N/D & $-0.9 /-1.5$ & $1.57-2.57$ & \\
\hline & & iii & $236-335$ & -22.4 & $-1.7 /-2.9$ & $2.90-4.80$ & \\
\hline & & iv & $246-251$ & N/D & $-0.1 /-2.0$ & $0.18-3.39$ & \\
\hline & & $\mathrm{v}$ & $245-263$ & -21.3 & $-1.2 /-2.4$ & $2.07-4.03$ & \\
\hline & & vi & $217-245^{* *}$ & N/D & $0.8 /-1.7$ & $1.40-2.90$ & \\
\hline \multirow[t]{13}{*}{ Endoskarn } & Grs & $\mathrm{i}$ & $266-303$ & -22.8 & $-0.8 /-1.8$ & $1.40-3.06$ & $\mathrm{NaCl}-\mathrm{KCl}-\mathrm{H}_{2} \mathrm{O}$ \\
\hline & & ii & $263-278^{* *}$ & -21.5 & $-0.9 /-1.5$ & $1.57-2.57$ & \\
\hline & & iii & 259-261 & -24.3 & $-1.7 /-2.9$ & $2.90-4.80$ & \\
\hline & & iv & 294-339 & N/D & $-0.1 /-2.0$ & $0.18-3.39$ & \\
\hline & & $\mathrm{v}$ & $293-346$ & -22.3 & $-1.2 /-2.4$ & $2.07-4.03$ & \\
\hline & $\mathrm{Di}$ & $\mathrm{i}$ & $226-280$ & -21.8 & $-1.9 /-2.3$ & $3.23-3.87$ & $\mathrm{H}_{2} \mathrm{O}-\mathrm{NaCl}$ \\
\hline & & ii & $258-328$ & -21.1 & $-1.9 /-2.2$ & $3.23-3.71$ & \\
\hline & & iv & $241-258$ & N/D & $-1.7 /-2.2$ & $2.90-3.71$ & \\
\hline & & vi & $251-276^{* * *}$ & -21.5 & $-1.5 /-2.3$ & $2.57-3.87$ & \\
\hline & Qtz & $\mathrm{i}$ & $241-337$ & $\mathrm{~N} / \mathrm{D}$ & $-2.2 /-4.9$ & $3.71-7.73$ & N/D \\
\hline & & ii & $236-243^{* *}$ & $\mathrm{~N} / \mathrm{D}$ & $\mathrm{N} / \mathrm{D}$ & N/D & \\
\hline & & iii & 239-323 & N/D & $-1.8 /-2.4$ & $3.06-4.03$ & \\
\hline & & iv & $233-258$ & N/D & $-2.3 /-3.1$ & $3.87-5.11$ & \\
\hline
\end{tabular}

${ }^{\text {a }} \mathrm{Th}=$ homogenisation temperature, Te = eutectic temperature, $\mathrm{Tm}=$ ice melting temperature. Temperatures are express in ${ }^{\circ} \mathrm{C}$ and salinity in eq. wt $\% \mathrm{NaCl}$. The saline system was determinated following Bodnar (1992) and Shepherd et al. (1985) methodologies. N/D = No determinated.

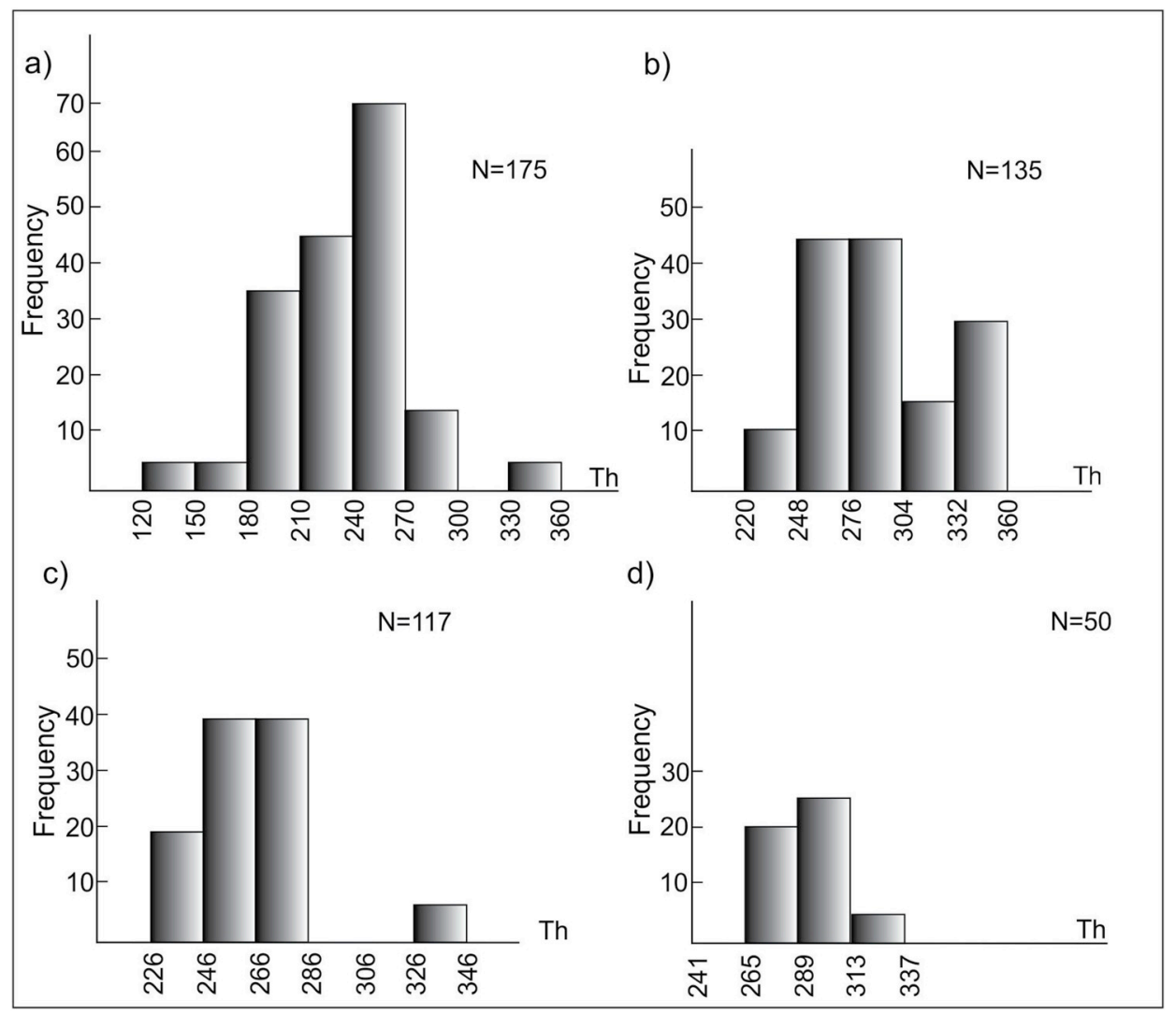

Fig. 11. Th (given in ${ }^{\circ} \mathrm{C}$ ) vs Frequency histogram. Measurements of FI hosted in: a) vesuvianite, b) grossular, c) diopside and d) quartz. 


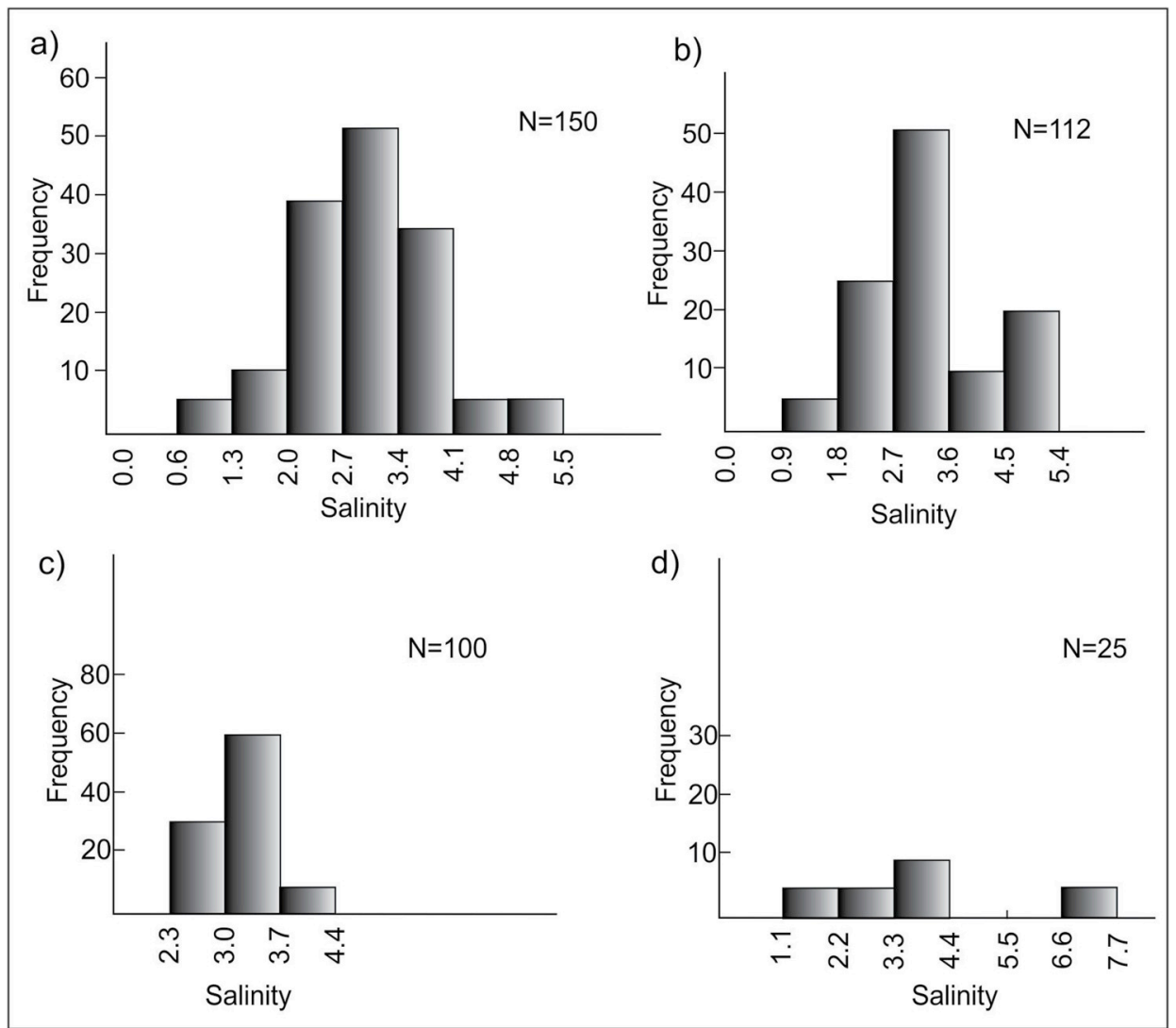

Fig. 12. Salinity (eq. wt $\% \mathrm{NaCl}$ ) vs Frequency histogram. Measurements of FI hosted in: a) vesuvianite, b) grossular, c) diopside and d) quartz.
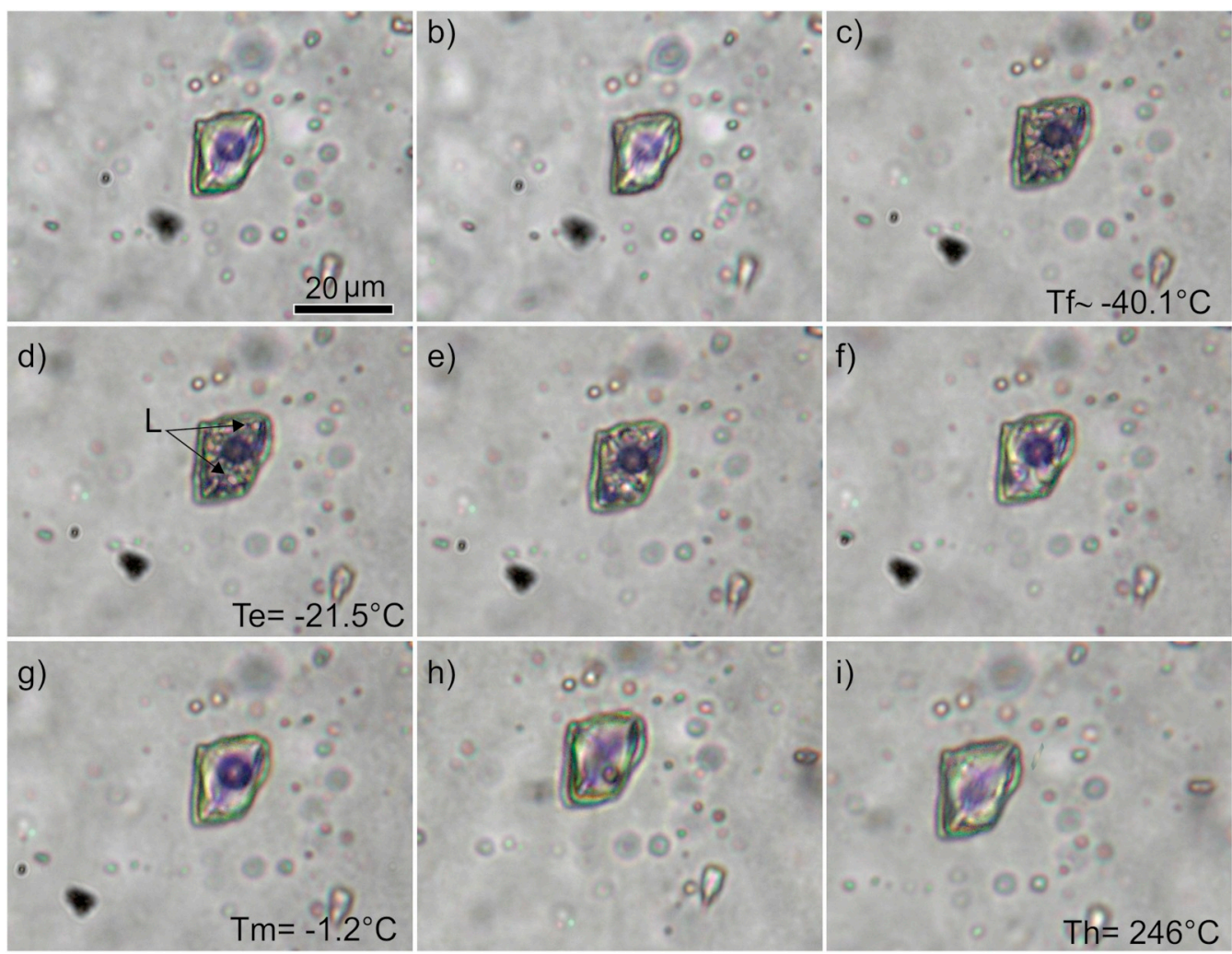

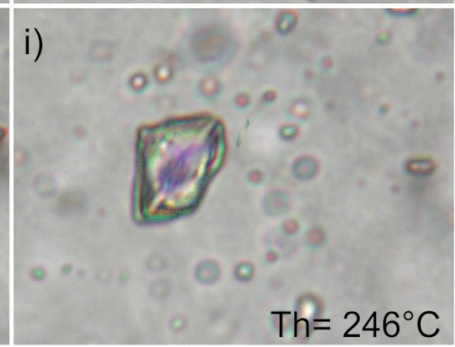

Fig. 13. Measurement routine of a type iii FI in a vesuvianite crystal. a and b) FI cooling. c) Near to the freezing temperature of the FI. d) The FI heating reveals the Te (eutectic) with the occurrence of the first drops of the liquid. e and f) FI heating; note how the ice crystals formed during cooling disappeared. g) Melting temperature of the last ice crystal $\left.\left(\mathrm{Tm}=-1.2^{\circ} \mathrm{C}\right) . \mathrm{h}\right)$ Following the FI heating process the bubble has reduced its volume. i) FI homogenisation temperature (Th) at $246^{\circ} \mathrm{C}$ with the disappearance of the gas bubble and homogenisation to liquid. 
a)

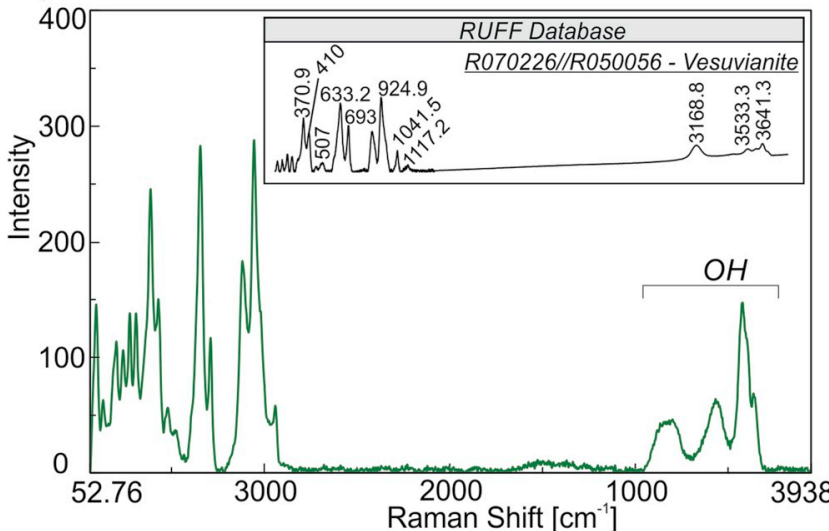

c)

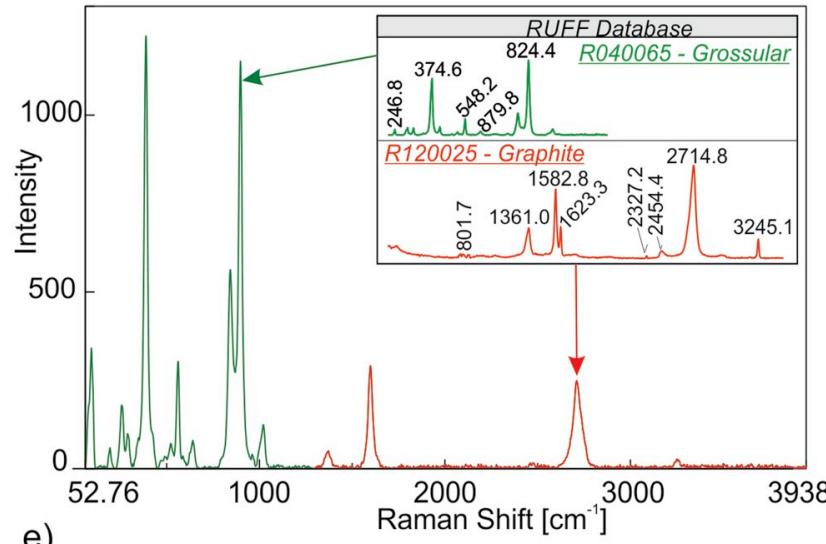

e)

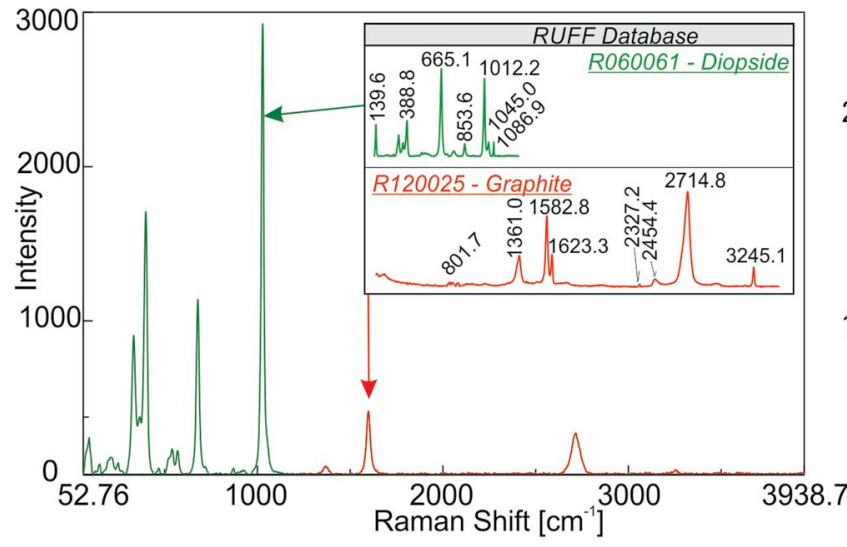

b)

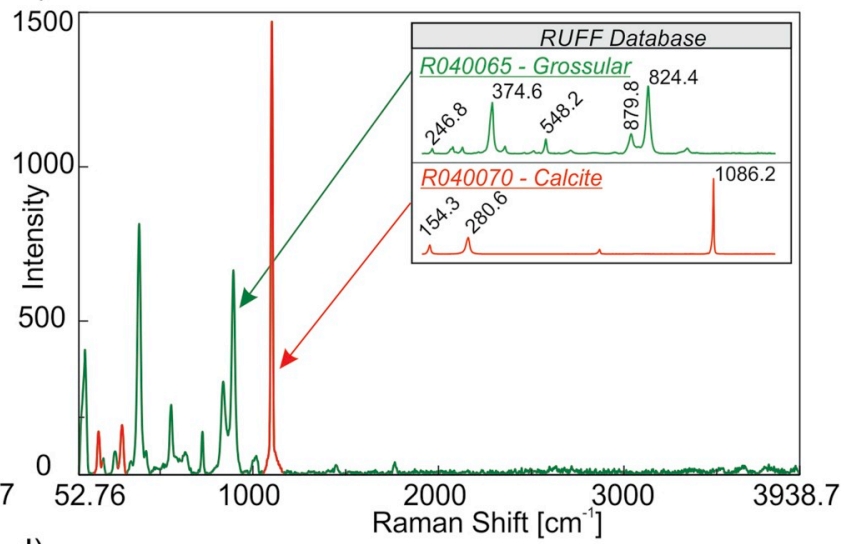

d)

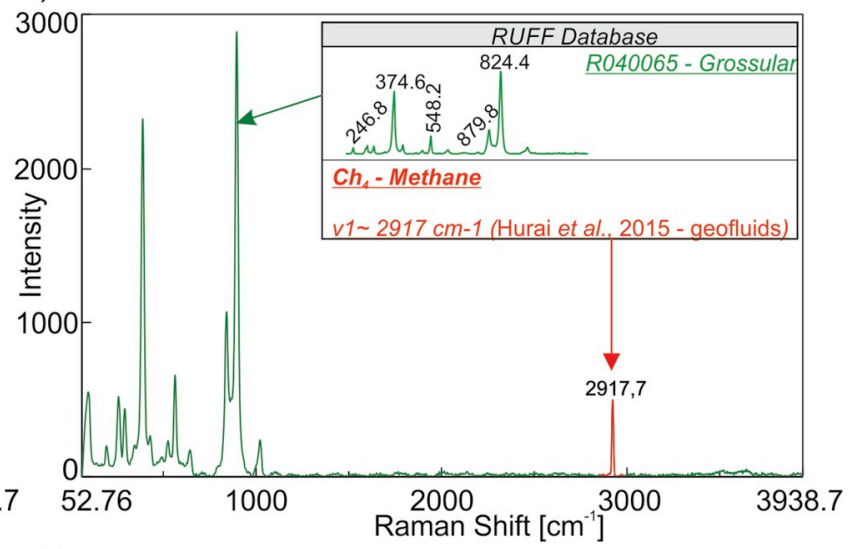

f)

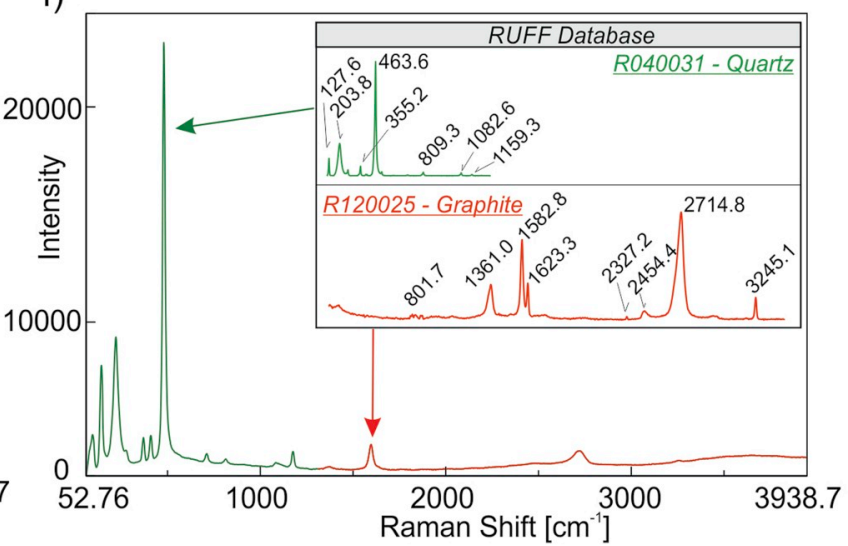

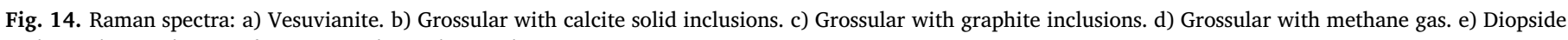
with graphite inclusions. f) Quartz with graphite inclusions.

graphite of both diopside and quartz, while $S_{2}$ band is absent in these two graphite samples (Fig. 15).

The average of the Raman parameters quantification and the $R_{1}$ relation $(D / G)$ for each sample are observed in Table 5 . The low variability of $R_{1}$ indicates that all the samples were affected by the same temperature conditions.

\section{Stable isotopes and isotopic geothermometry}

$\delta^{18} \mathrm{O}_{\mathrm{V} \text {-SMow }}$ determinations were made on concentrates of wollastonite and vesuvianite (exoskarn), and grossular and diopside (endoskarn). The results are summarised in Table 6 and in Fig. $16 \delta^{18} \mathrm{O}_{\mathrm{V}}$ Smow values of calcite were taken from Lajoinie et al. (2013 and 2014b). $\delta^{18} \mathrm{O}_{\mathrm{V}-\mathrm{Smow}}$ values in calcite crystals range between +13.4 and $+17.3 \%$, and they yielded values of $+10.2 \%$ in vesuvianite and $+9.0 \%$ in wollastonite and diopside crystals. On the other hand, $\delta^{18} \mathrm{O}_{\mathrm{V} \text { - }}$ smow shows values around $+8.0 \%$ in grossular and $+9.0 \%$ in diopside from endoskarn.

Oxygen isotope systematics of the San Miguel area was used for isotopic thermometry, in order to get an independent estimate of the formation temperature of the skarn. The calcite-vesuvianite pair gave temperatures of about $653{ }^{\circ} \mathrm{C}$ (using experimental coefficients from Zheng, 1999 and 1993a), the wollastonite-vesuvianite pair indicated $654^{\circ} \mathrm{C}$ (following Zheng, 1993a and b coefficients), and finally the diopside-grossular pair gave temperatures of $642^{\circ} \mathrm{C}$ (using experimental coefficients from Valley, 2003). These equilibrium temperatures are clearly higher than those obtained by FI analyses, probably as a 


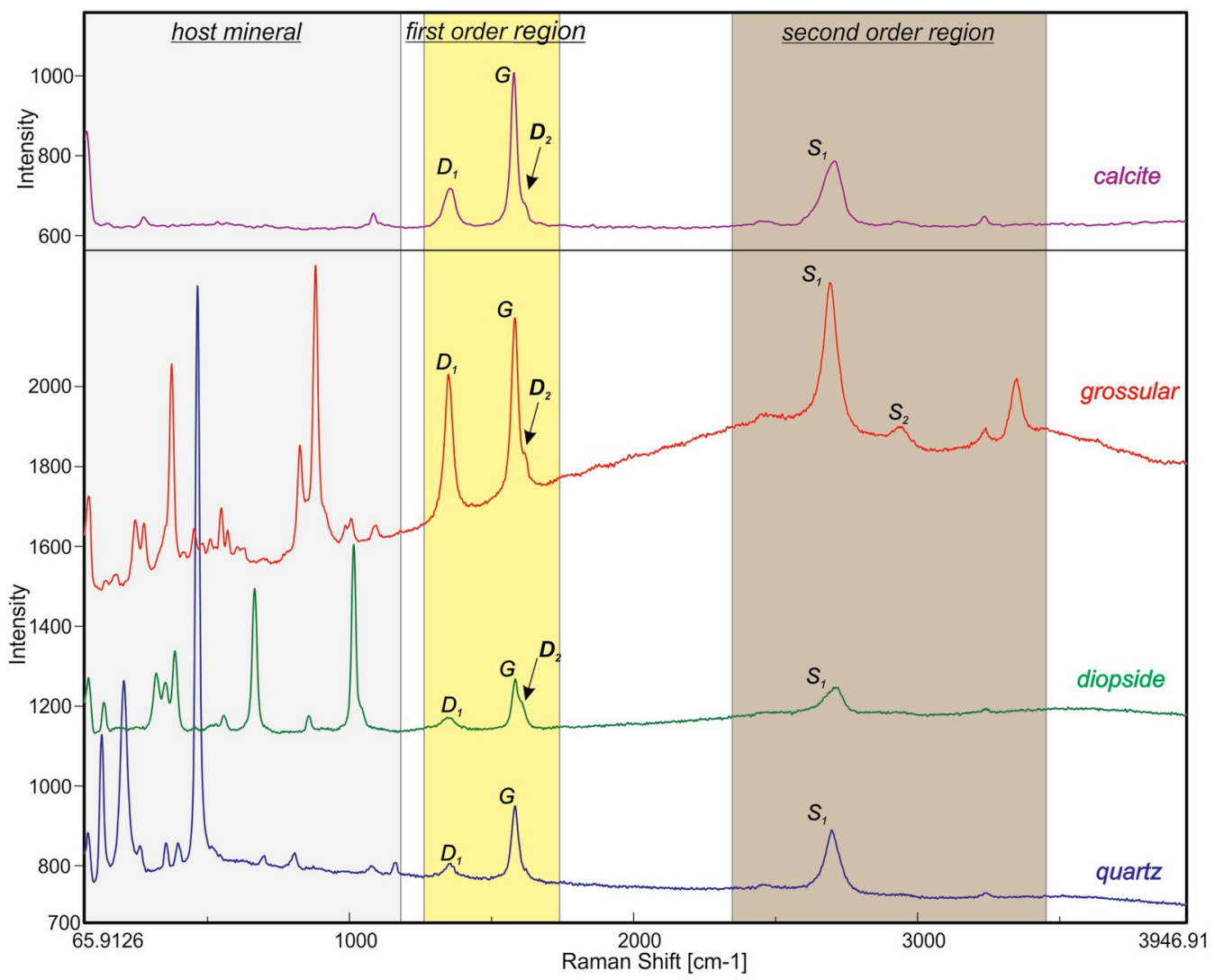

Fig. 15. Graphite Raman spectra in: calcite, grossular, diopside and quartz. The "first order region" bands $G, D_{1}$ and $D_{2}$ and the "second order region" overtones $S_{1}$ and $S_{2}$ are indicated.

Table 5

Raman quantitative parameters (mean values of the position, full width at half maximum and R1 index) from solid inclusions hosted by calcite and fluid inclusions hosted by grossular, diopside and quartz.

\begin{tabular}{|c|c|c|c|c|c|c|c|c|c|}
\hline Host mineral & $\mathrm{N}$ & G & G-FWHM & $\mathrm{D}_{1}$ & D-FWHM & $\mathrm{D}_{2}$ & $\mathrm{~S}_{1}$ & $\mathrm{~S}_{2}$ & $\mathrm{R}_{1}(\mathrm{D} / \mathrm{G})$ \\
\hline Calcite & 23 & 1580.09 & 24.16 & 1353.96 & 42.93 & 1615.03 & 2705.48 & - & 0.857 \\
\hline Garnet & 28 & 1582.31 & 25.66 & 1352.44 & 32.01 & 1610.38 & 2697.24 & 2835.91 & 0.855 \\
\hline Diopside & 17 & 1583.93 & 23.24 & 1354.42 & 50.36 & 1599.50 & 2709.85 & - & 0.855 \\
\hline Quartz & 28 & 1582.44 & 26.45 & 1350.38 & 36.97 & - & 2703.05 & - & 0.853 \\
\hline
\end{tabular}

FWHM: full width at half maximum.

Table 6

Oxygen isotopic determinations from the San Miguel skarn minerals.

\begin{tabular}{lll}
\hline Location & Mineral & $\delta^{18} \mathrm{O}_{\text {V-SMOW }}(\% 0)$ \\
\hline \multirow{2}{*}{ Exoskarn } & calcite $^{\mathrm{a}}$ & +13.40 \\
& calcite $^{\mathrm{a}}$ & +15.50 \\
& calcite $^{\mathrm{a}}$ & +17.30 \\
& wollastonite & +9.10 \\
& vesuvianite & +10.20 \\
\cline { 2 - 3 } Endoskarn & grossular & +8.10 \\
& grossular & +8.00 \\
& diopside & +9.00 \\
\hline
\end{tabular}

a Data from Lajoinie et al. (2014b). result of the pressure involved in the formation of these rocks which can affect the temperature of the trapped FI, but not the temperature of isotopic equilibrium.

\section{Discussion}

\subsection{Metasomatic fluid characterisation}

Fluids involved in the San Miguel skarn formation were characterised by fluid inclusion microthermometry, Raman spectroscopy and stable isotope analysis performed on different calc-silicate paragenesis. FI hosted in vesuvianite from the exoskarn, and in grossular (Grs $93.06-93.92-\mathrm{Alm}_{2.78-4.25}-\mathrm{Adr}_{1.63-3.36}$ ), diopside ( $\mathrm{Di}_{79.70-86.19}-\mathrm{Hd}_{13.70-}$ $\left.20.09-\mathrm{Jo}_{0.11-0.25}\right)$ and quartz from the endoskarn were studied. The 


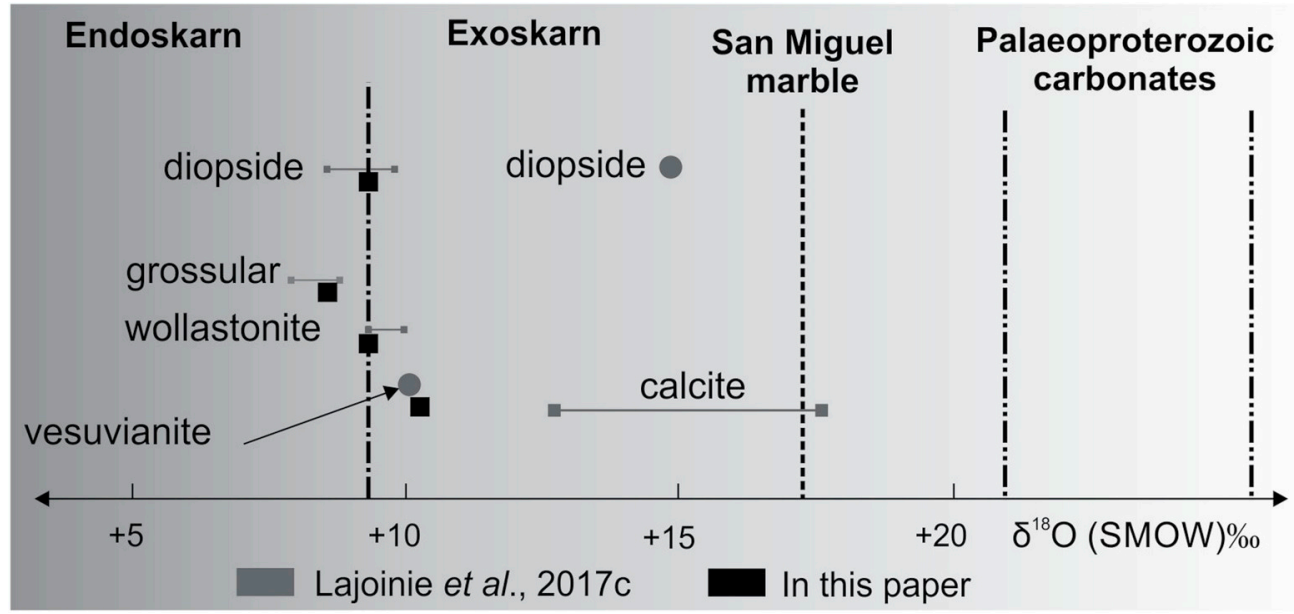

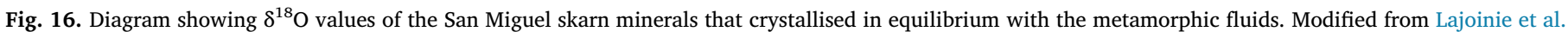
(2017c).

measured Th indicates that these minerals were formed from a fluid at a moderate temperature, between 250 and $320^{\circ} \mathrm{C}$, and although these minerals are disposed in a zonal pattern paragenesis, the range of the homogenisation temperatures is similar for all minerals. Another characteristic of this fluid is its low salinity ( $<7 \mathrm{wt} \% \mathrm{NaCl}$ eq.), so the crystals found inside the poliphasic FI would not correspond to daughter crystals. The solid phases found in some FI correspond to trapped minerals, such as Mg-rich calcite and graphite in some cases. Therefore, types ii and vi FI correspond to types i and vi FI, respectively, which have incorporated mineral crystals derived from marble during their formation. The presence of $\mathrm{Mg}$-rich calcite would indicate that part of the $\mathrm{Mg}^{2+}$ used to form diopside. This would have been during the regional metamorphic and metasomatic processes derived from the carbonate and metamorphic fluid. Furthermore, this Mg-rich calcite could represent the original composition of the protolith since the only information available from the metamorphic marble is that determined by Lajoinie et al. (2018), which pointed out only up to $1 \% \mathrm{MgO}$ (attributed to the diopside presence).

The measured Te between -24.2 and $-21.5^{\circ} \mathrm{C}$ indicates an aqueous system predominately $\mathrm{NaCl}-\mathrm{H}_{2} \mathrm{O} / \mathrm{NaCl}-\mathrm{KCl}-\mathrm{H}_{2} \mathrm{O}$, typical of a fluid with possible magmatic origin (Roedder, 1971; Bodnar, 1995; Meinert et al., 2005). Moreover, the absence of $\mathrm{CO}_{2}$ as an immiscible gas in the analysed FI (confirmed by Raman Spectroscopy) would indicate that the $\mathrm{CO}_{2}$ generated during the decarbonation reactions was removed from the system or diluted by the incorporation of more aqueous fluid, keeping its concentration low and relatively constant. Although $\mathrm{CO}_{2}$ is an expected phase in this type of system, its absence has already been mentioned in the San Marcos Sierra, La Falda, Cañada del Puerto and Copina skarns (eastern Pampeanas Ranges; Franchini et al., 1998a and b; 1999). These skarns were formed by the interaction of metamorphic rocks of the Neoproterozoic basement and granite igneous bodies, rich in aqueous fluids. Also, they have a similar mineralogical composition to the San Miguel skarn with zonal distribution rich in wollastonite, vesuvianite and grossular. It is also important to note that during the formation period of the San Miguel skarn (Transamazonian Cycle), a large production of water-rich fluids is estimated by the crystallisation of leucosomes (Delpino, 2000). The values of oxygen stable isotopes determined on vesuvianite, wollastonite and calcite of the exoskarn and diopside and grossular of the endoskarn, show a range of variation generated by the interaction of the aqueous fluid and the calcite marble. According to Lajoinie et al. (2017c), this variation is strongly associated with the position of the mineral in respect to the two oxygen sources: the fluid and the marble (Fig. 16). A large difference $\delta^{18} \mathrm{O}$ in values between the marble and the calc-silicates $(\sim 13-17 \%$ and $\sim 8-10 \%$, respectively) can be observed. This fact, together with the absence of $\mathrm{CO}_{2}$ in the FI, reveals the limited effect of the carbonate protolith in the calc-silicate crystallisation. Furthermore, $\delta^{18} \mathrm{O}$ values indicated isotopic equilibrium temperatures of $642-654^{\circ} \mathrm{C}$. These temperatures are higher than the Th of the measured FI. However, considering that mineral crystallisation occurred (according to the geological context) under regional metamorphic conditions (amphibolite facies) this temperature difference could be attributed to pressure effects over the FI. It is remarkable that isotopic equilibriums are usually not sensitive to pressure effects (Hoefs, 2009). In this sense, the vesuvianite, grossular, diopside and quartz isochores, at a pressure of 5-6 kbars (according to external barometric data obtained for this basement) (Delpino and Dristas, 2008; Martínez et al., 2016; Massonne, 2012) were obtained. They have been calculated with the FLINCOR program (Brown, 1989) for the $\mathrm{H}_{2} \mathrm{O}-\mathrm{NaCl}$ system (Zhang and Frantz, 1987; Bodnar and Vityk, 1994). Although in deposits formed at low temperatures and high salinity, the correction caused by pressure does not generally exceed $25^{\circ} \mathrm{C}$ (Velasco, 2004), in those formed at high temperatures and low salinity, the increase in pressure increases the order of correction above $300^{\circ} \mathrm{C}$ (Bodnar, 2003). Thus, the pressure corrections in the order of $400{ }^{\circ} \mathrm{C}$ obtained by the comparison between the isochores with the independent pressure data are suitable, as shown in Fig. 17. In consequence, the real trapping temperatures would rise to $630-720^{\circ} \mathrm{C}$. Even though this temperature correction must be corroborated in future investigations through the application of a local geobarometer, it is quite close to the temperature obtained for the isotopic equilibrium $\left(642-654^{\circ} \mathrm{C}\right)$ and even more than the range of $630-650^{\circ} \mathrm{C}$ obtained for the minimum pressure ( $5 \mathrm{kbars}$ ). Moreover, certain vesuvianite characteristics such as the F content > $0.50 \%$ and the $P 4 / n n c$ symmetry, determined by Lajoinie et al. (2012), indicate that this mineral was formed at a high temperature $>500{ }^{\circ} \mathrm{C}$ (Groat and Hawthorne, 1998; Borovikova and Kurazhkovskaya, 2005).

\subsection{Graphite characterisation}

Raman spectroscopy allowed opaque minerals, previously described in section 7.1.2, to be identified as graphite in the FI present in grossular, diopside, quartz and calcite. No carbonaceous phases were found in vesuvianite thus, it is possible to infer that carbon-bearing phases (gaseous or solid) were not present in the initial composition of the fluid. This is given that the vesuvianite is one of the first minerals to be formed in metasomatic processes (Bowman and Essene, 1984). Graphite formation in metamorphic systems can be generated by the transformation of organic matter that was trapped in sedimentary rocks (syngenetic-biogenic), or by precipitation from a fluid-bearing carbon (epigenetic; Crespo et al., 2004; Luque et al., 2012). Also, a possible 
a)

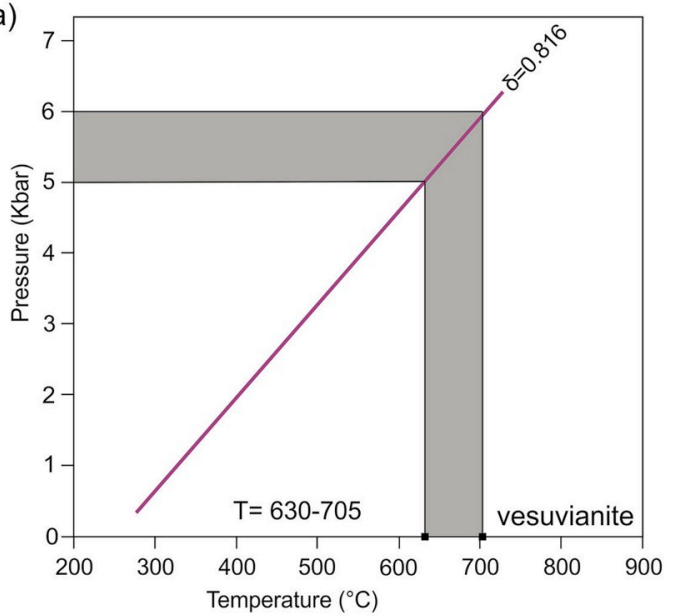

c)

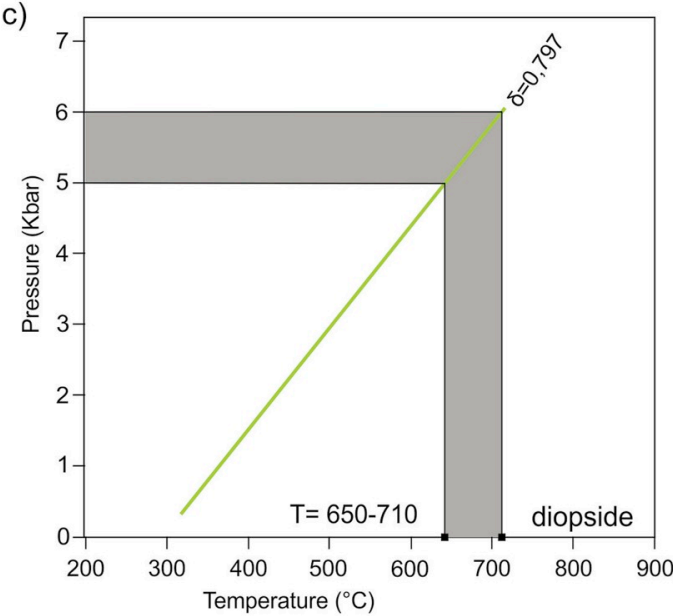

b)

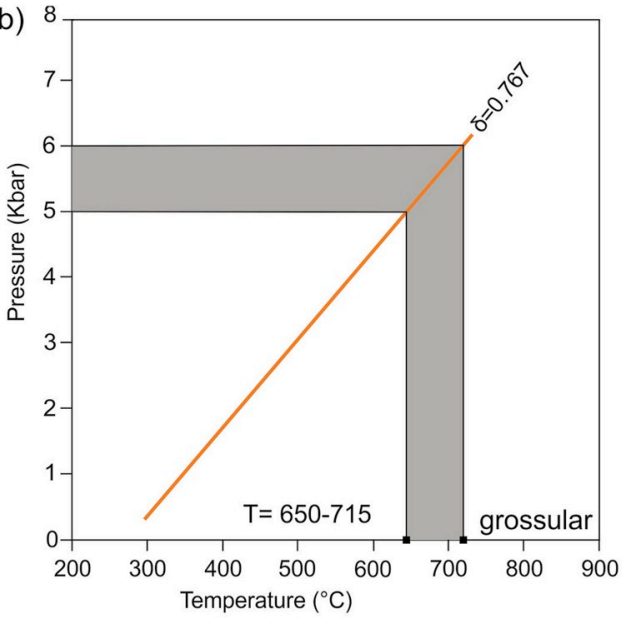

d)

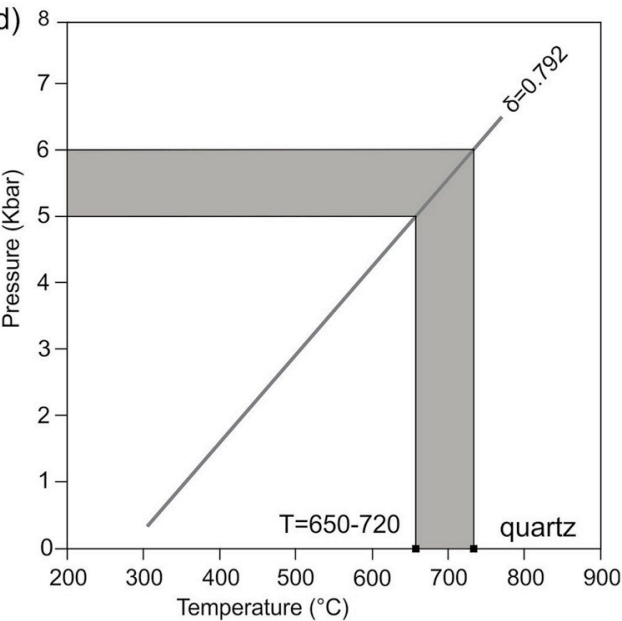

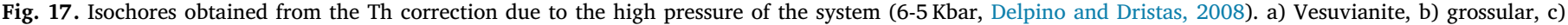
diopside and d) quartz.

mixing of $\mathrm{CO}_{2}$ with aqueous fluids during skarn formation and metasomatic processes can provoke graphite precipitation (Nokleberg, 1973). In the latter case the incorporated $\mathrm{CO}_{2}$ reacts with $\mathrm{H}_{2} \mathrm{O}+\mathrm{H}_{2}$ (at temperatures of $527-827{ }^{\circ} \mathrm{C}$ and $\sim 2$ kbars of pressure) to form $\mathrm{CO}+\mathrm{CH}_{4}$. This reaction elevates the oxygen fugacity of the fluid allowing andradite-rich garnet and hedenbergite-rich clinopyroxene to be crystallised near to the metasomatised marble (Nokleberg, 1973). In the San Miguel skarn, the aqueous nature of the fluid involved indicates that the precipitation from a fluid-bearing-carbon could not be the mechanism of the graphite formation but a possible mixing of the $\mathrm{CO}_{2}$, generated during the decarbonation reactions with the aqueous fluid. However, the garnet crystal composition indicates a lower molecular proportion of andradite with respect to almandine, reflecting no oxidising conditions. In addition, from the presence of graphite in the farthest sectors of the metasomatic front, it is inferred that the graphite and the $\mathrm{CH}_{4}$ would have been formed by the transformation of organic matter present in the marine sedimentary protolith, deposited during the "Lomagundi-Jatuli" even, throughout the metamorphic/metasomatic process. It is important to note that during the "Lomagundi-Jatuli" event, an increase in the proportion of organic matter and atmospheric oxygen generated the precipitation of isotopically heavy carbonates (Melezhik et al., 2005). In this sense, it should be mentioned that the crystallinity degree of the syngenetic-biogenic graphite is associated with the increase of the metamorphic grade (Wopenka and Pasteris, 1993; Beyssac et al., 2002); where graphite concentrations with different degrees of crystallinity are frequently found. However, the epigenetic graphite always presents a high crystallinity in spite of being precipitated under low temperature conditions (Luque et al., 1998, 2009). The graphite identified in calcite, grossular, diopside and quartz is evidence of different crystallinity degrees like the syngentic graphite. This is according to variations in parameters such as: the position, intensity and definition (narrow $v s$. broad) of $\mathrm{G}, \mathrm{D}_{1}$ and $\mathrm{D}_{2}$ bands (identified in the first order region), and the presence or absence of $S_{2}$ band (in the second order region) (Fig. 15 and Table 5). The spectrum of graphite in grossular (Fig. 16) is similar to semi-graphite (Rantitsch et al., 2016), while the spectra obtained in diopside, quartz and calcite are more similar to graphite samples.

Although the disordered-graphite identification through Raman spectroscopy studies is not sufficient to define the origin of the carbonaceous material (Pasteris and Wopenka, 2003), in the geological context in which the skarn carbonate-protolith was formed, the transformation of the organic matter would be the most acceptable source for the graphite formation. In this sense, the methane identified in some biphasic FI hosted in grossular would have formed from the decomposition of semi-graphite in presences of water-rich fluid. This is because carbonaceous materials with a low graphitic degree show a greater initial reaction than that of carbonaceous materials with a high graphitic degree (associated with a high concentration of reactive sites) (Calderón et al., 2017). 

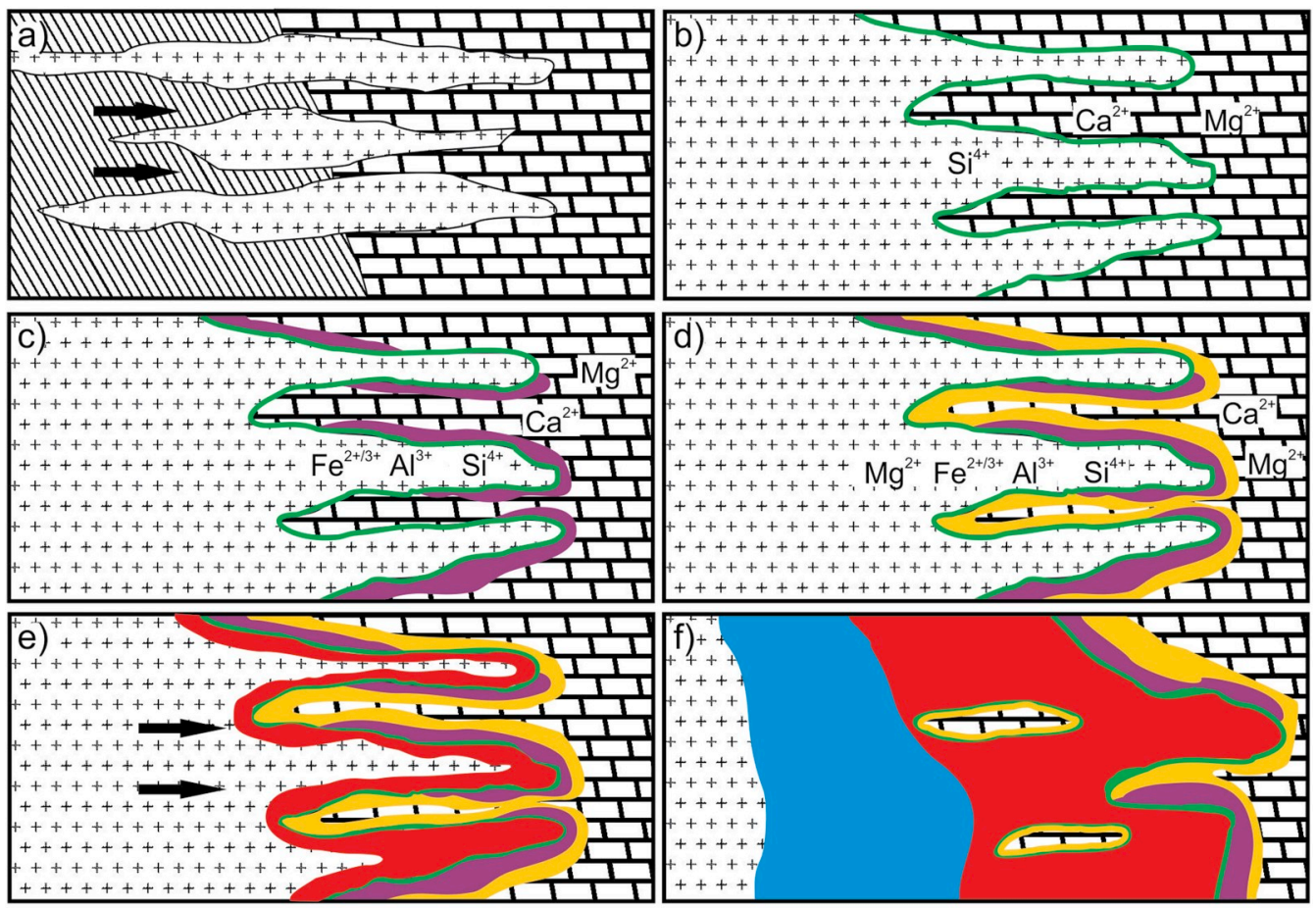

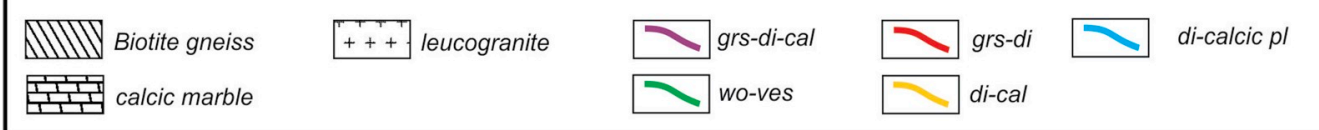

Fig. 18. San Miguel skarn evolution scheme, where the development of the different mineral zones is displayed. a) Leucosome produced by the gneiss partial melting, intruded the marble. Exoskarn development of the: b) wollastonite-vesuvianite zone, c) grosullardiopside zone and d) diopside zone. Endoskarn: e) advance of the metasomatic front and consequent grossulardiopside zone formation. f) Development of the diopside-calcic plagioclase zone. Mineral abbreviations according to Kretz (1983).

\subsection{Mineral zonation model}

According to the obtained results, the San Miguel skarn mineral zonation (wollastonite-vesuvianite, grossular-diopside-calcite and diopside-calcite in the exoskarn, and grossular-diopside and diopsidecalcic plagioclase in the endoskarn) would not respond to significant changes in the temperature or $\mathrm{CO}_{2}$ concentration in the fluids, but to modifications in the gradients of the cation activities such as $\mathrm{Si}^{4+}$, $\mathrm{Ca}^{2+}, \mathrm{Mg}^{2+}, \mathrm{Fe}^{2+}, \mathrm{Fe}^{3+}$ and $\mathrm{Al}^{3+}$, (Bowman, 1998). Nearby the leucogranite-carbonate rock contact in the "stationary reaction front" (Dipple and Gerdes, 1998), aqueous fluids accumulate together with a high $a\left(\mathrm{Ca}^{2+}\right)$, promoting the necessary conditions for the wollastonite formation through the first decarbonation reactions (Fig. 18a). In this sense, activity diagrams for aqueous systems $a\left[\left(\mathrm{Ca}^{2+} /\left(\mathrm{H}^{+}\right)\right]\right.$vs $a$ $\left[\left(\mathrm{Al}^{3+}\right) /\left(\mathrm{H}^{+}\right)\right]$and $a\left[\left(\mathrm{Ca}^{2+} /\left(\mathrm{H}^{+}\right)\right]\right.$vs $a\left[\left(\mathrm{Mg}^{3+}\right) /\left(\mathrm{H}^{+}\right)\right]$(Bowers et al., 1984) show that high values of $a\left[\left(\mathrm{Ca}^{2+} /\left(\mathrm{H}^{+}\right)\right]\right.$are required to stabilise the wollastonite formation reaction. The progressive increase in the ion activities, such as $\mathrm{Mg}^{2+}$ and $\mathrm{Fe}^{2 / 3+}$, which have lower diffusion velocities than $\mathrm{Al}^{3+}$ and $\mathrm{Si}^{4+}$ (Meinert et al., 2005), have caused the vesuvianite formation that completed the wollastonite-vesuvianite paragenesis (Bowman, 1998, Fig. 18b). This association (vesuvianite + wollastonite), at temperatures above $500{ }^{\circ} \mathrm{C}$, is only stable up to a $\mathrm{X}_{\mathrm{CO} 2}<0.01$, since at higher values of $\mathrm{X}_{\mathrm{CO} 2}$ minerals such as garnet or clinopyroxene are added (Bowman, 1998). The increase in the fluid flow must have incremented the mobilisation of $\mathrm{Al}^{3+}$ and even more of $\mathrm{Si}^{4+}$ (Meinert et al., 2005), which allowed the grossular garnet to be crystallised, inhibiting the wollastonite formation (Bowman and Essene, 1984). Even under these conditions, the $\mathrm{X}_{\mathrm{CO} 2}$ must have been lower than 0.05 , which corresponds to the stability limit value of the vesuvianite + grossular association (Bowman, 1998, Fig. 18c).

The increase in the $\mathrm{Ca}^{2+}, \mathrm{Fe}^{+3 / 2}$ and $\mathrm{Mg}^{+2}$ contents in the siliceous fluids favoured the crystallisation of diopside in the exoskarn (Fig. 18d) at $\mathrm{X}_{\mathrm{CO} 2}<0.11$ (Bowman and Essene, 1984; Bowman, 1998). Finally, the grossular-diopside zones and diopside-calcic plagioclase were formed from the partial assimilation of the exoskarn by the leucogranite intrusion (Quartino and Villar Fabre, 1967; Lajoinie et al., 2013; Lajoinie, 2015). This fact generated grossular and diopside incorporation, and more Ca enrichment into the endoskarn provoking the crystal size increment and the calcic-plagioclase crystallisation (Fig. 18e).

The described mineral zonation was not fully identified in San Miguel (SS) and La Concordia farms, probably due to the lack of wellexposed outcrops. Although a complete section of the skarn is observable in the Siempre Verde farm quarry, its advanced meteorisation does not allow it to be geochemically and microthermometricaly studied. However, no evidence of vesuvianite or garnet presence was found. Given that the crystallisation of these minerals in the early stages of many skarns indicates low $\mathrm{X}_{\mathrm{CO} 2}$, its absence in the San Miguel skarn could be attributed to: 1 ) the incorporation of $\mathrm{CO}_{2}$ in the fluid during decarbonation reactions, or 2) the predominance of assimilation processes with respect to the metasomatic ones, generated by a low fluidrock (marble) ratio.

\subsection{Tectonic implications of syngenetic graphite presence}

The finding of possible syngenetic graphite in FI of basement rock minerals of the Tandilia Belt has significant implications for the origin of the studied metamorphic rocks and the tectonic setting. Basins located between continental masses, that later evolved to suture zones, have been indicated as appropriate places for the accumulation and preservation of carbonaceous matter (Crespo et al., 2004; Dissanayake et al., 2000). Subsequently, metamorphism could transform these sedimentary rocks into metamorphic ones with the trapped organic matter in graphite (graphitisation; Wopenka and Pasteris, 1993). According to Chernicoff et al. (2014), the southern region of the Río de la Plata Craton formation involved the amalgamation of three Neoarchaean terranes: Balcarce, Tandilia and Buenos Aires (Fig. 1a; Santos et al., 2017b and references therein), and the closure of possible marine 
basins. The new information provided in this paper indicates that the San Miguel area rocks would have formed in a Siderian to Rhyacian marine sedimentary basin in which organic matter was accumulated. Depleted mantle model ages of 3.05 to $2.47 \mathrm{Ga}$ were indicated as the maximum age for the marble (Lajoinie et al., 2018), while the $\mathrm{Rb}-\mathrm{Sr}$ age of $2.12 \pm 0.01 \mathrm{Ga}$, determined for the leucogranite intrusion (Halpern et al., 1970), would be considered as the minimum age of the carbonate deposition; thus, the organic matter accumulation must have occurred during the same period as the formation of this marble. There is wide and varied evidence recorded that indicates the existence of bacterial ecosystems in the Precambrian times (Han and Runnegar, 1992; Dissanayake et al., 2000 and references therein). Furthermore, it is accepted that the organic matter presence in Proterozoic sedimentary basins would have been abundant (Schidlowski and Aharon, 1992; Schidlowski, 1995). In this context, detailed future investigations (C and $\mathrm{O}$ stable isotope studies supplemented by LA-ICP-MS and Raman spectroscopy) aim to characterise the graphite present in the Palaeoproterozoic basement of the San Miguel area and to identify the oldest records of life for Argentina in the Tandilia Belt basement.

\section{Conclusions}

The characterisation of the fluid involved in the San Miguel skarn formation and the identification of graphite inclusions in the skarn minerals in the carbonatic-protolith allowed the following main conclusions to be developed:

1. The San Miguel skarn would have formed from the interaction between an aqueous fluid with low salinity ( $<7 \mathrm{wt} \% \mathrm{NaCl}$ eq.) derived from a saline system $\left(\mathrm{NaCl}-\mathrm{H}_{2} \mathrm{O} / \mathrm{NaCl}-\mathrm{KCl}-\mathrm{H}_{2} \mathrm{O}\right)$, typical of a magmatic-metamorphic environment and a "Lomagundi-Jatuli event" calcitic marble.

2. Crystallisation of skarn minerals occurred between 630 and $650{ }^{\circ} \mathrm{C}$ (at 5 bars), according to fluid inclusion microthermometric data, and between 642 and $654^{\circ} \mathrm{C}$ based on stable isotope equilibrium.

3. The skarn mineral zoning was generated by differences in the $\mathrm{Ca}^{2+}$, $\mathrm{Mg}^{2+}, \mathrm{Fe}^{2 / 3+}, \mathrm{Si}^{+4}$ and $\mathrm{Al}^{+3}$ cation activities and not by significant temperature changes or variation in $\mathrm{CO}_{2}$ concentration.

4. Raman spectroscopy studies showed that graphite inclusions identified in grossular, diopside, quartz and calcite crystals, have a different crystallinity degree between semi-graphite and graphite.

5. A possible biogenic origin for the graphite is postulated since: the involved fluid composition is aqueous (no $\mathrm{CO}_{2}$ was found), the graphite showed variations in its crystallinity, and its present both in the skarn minerals and in the calcite of the protolithic marble was formed during an increase in organic carbon productivity ("Lomagundi-Jatuli event").

6. The evidence of marine carbonate rocks (skarn protolith) with possible organic matter (subsequently graphitisated) in the Tandilia Belt basement could be the marine-sedimentary-basin relict, which was developed during the Siderian-Rhyacian period and completed during the Transamazonian Orogeny $(2.2-2.0 \mathrm{Ga})$.

\section{Acknowledgments}

Financial support was provided by the Comisión de Investigaciones Científicas de la Provincia de Buenos Aires and by the Universidad Nacional de La Plata through the $11 \mathrm{~N}-617$ and $11 \mathrm{~N}-716$ projects. The microprobe analyses were carried out with the assistance of Dr. A. Martín-Izard at the Departamento de Geología, Universidad de Oviedo (Spain). We thank to the Consejo Nacional de Investigaciones Científicas y Técnicas. We also want to express our gratitude to Mr. Miguel Catella, Mr. Luis Magnasco, and the Anchorena Foster family for their hospitality during our visits to the study area.

\section{Appendix A. Supplementary data}

Supplementary data to this article can be found online at https:// doi.org/10.1016/j.jsames.2018.11.008.

\section{References}

Almeida, F.F.M., Amaral, G., Cordani, U.G., Kawashita, K., 1973. The precambrian evolution of the south American cratonic margin, south of the Amazon river. In: In: Nairn, A.E., Stehli, F.G. (Eds.), The Ocean Basins and Margins, vol. 1. Plenum Publishing, New York, pp. 411-446.

Arrouy, M.J., Poiré, D.G., Gómez Peral, L.E., Canalicchio, J.M., 2016a. Sedimentología y estratigrafía del grupo La Providencia (nom. nov.): cubierta superior neoproterozoica, Sistema de Tandilia, Argentina. Lat. Am. J. Sedimentol. Basin Anal. 22, 171-189.

Arrouy, M.J., Warren, L.V., Quaglio, F., Poiré, D.G., Simões, M.G., Rosa, M.B., Gómez Peral, L.E., 2016b. Ediacaran discs from South America: probable soft-bodied macrofossils unlock the paleogeography of the Clymene Ocean. Sci. Rep. 6, 30590. https://doi.org/10.1038/srep30590.

Beyssac, O., Goffé, B., Chopin, C., Rouzaud, J.N., 2002. Raman spectrum of carbonaceous material in metasediments: a new geothermometer. J. Metamorph. Geol. 20, 859-871.

Bodnar, R.J., 1992. Revised equation and table for freezing point depressions of $\mathrm{H}_{2} \mathrm{O}$-salt fluid inclusions. In: $9^{\circ}$ Biennial Pan-American Conference on Research on Fluid Inclusions, Program and Abstracts, Lake Arrowhead.

Bodnar, R.J., 1995. Fluid-inclusion evidence for magmatic source for metals in porphyry copper deposits. Mineralogical Association of Canada, Short Course Series 23, $139-152$.

Bodnar, R.J., 2003. Introduction to aqueous fluid systems. In: In: Samson, I., Anderson, A., Marshall, D. (Eds.), Fluid Inclusions: Analysis and Interpretation, vol. 32. Mineralogical Association of Canada, Short Course, pp. 81-99.

Bodnar, R.J., Vityk, M.O., 1994. Interpretation of microthermometric data for $\mathrm{H}_{2} \mathrm{O}-\mathrm{NaCl}$ fluid inclusions. In: deVivo, B., Frezzotti, M.L. (Eds.), Fluid Inclusions in Minerals: Methods and Applications. Short Course IMA. VPI Press, pp. 117-130.

Borovikova, E.Y., Kurazhkovskaya, E.S., 2005. Infrared spectra and factor group analysis of vesuvianites in $\mathrm{OH}$ region. Vib. Spectrosc. 39, 95-98.

Borthwick, J., Hasmon, R.S., 1982. A note regarding $\mathrm{ClF}_{3}$ as an alternative for $\mathrm{BrF}_{5}$ for oxygen isotope analysis. Geochem. Cosmochim. Acta 46, 1665-1668.

Bossi, J., Cingolani, C., 2009. Extension and general evolution of the Río de la Plata Craton. In: Gaucher, C., Sial, A.N., Halverson, G.P., Frimmel, H.E. (Eds.), Neoproterozoic-cambrian Tectonics, Global Change and Evolution: a Focus on Southwestern Gondwana. vol. 16. Elsevier, Netherlands, pp. 73-85 Developments in Precambrian Geology.

Bowers, T.S., Jackson, K.L., Helgenson, H.C., 1984. Equilibrium Activity Diagrams. Springer-verlag, Berlin.

Bowman, J.R., 1998. Stable-Isotope systematics of skarns. In: In: Lentz, D.R. (Ed.), Mineralized Intrusion Related Skarn Systems, vol. 26. Mineralogical Association of Canada, Short Course Series, pp. 99-145.

Bowman, J.R., Essene, E.J., 1984. Contact Skarn formation at Elkhorn, Montana; I, P-T component activity conditions of early skarn formation. Am. J. Sci. 284, 597-650.

Brown, P.E., 1989. FLINCOR: a microcomputer program for the reduction and investigation of fluid inclusion data. Am. Mineral. 74, 1390-1393.

Calderón, L.A., Chamorro, E., Espinal, J.F., 2017. Understanding the kinetics of carbonhydrogen reaction: insights from reaction mechanisms on zigzag edges for homogeneous and heterogeneous formation of methane. Carbon 118, 597-606.

Camozzatto, E., Philipp, R.P., Chemale Jr., F., 2013. Idades Estaterianas no Domo da Vigia: Complexos Vigia e Porongos, Metagranito Seival e Anfibolito Tupi Silveira, Bagé, RS. In: $8^{\circ}$ International Symposium on Tectonics, $14^{\circ}$ Simpósio Nacional de Estudos Tectônicos. Chapada dos Guimarães, vol. 1 SBG-MT, Cuiabá (CD-ROM).

Chernicoff, C.J., Zappettini, E.O., Peroni, J., 2014. The Rhyacian El Cortijo suture zone: aeromagnetic signature and insights for the geodynamic evolution of the southwestern Río de la Plata Craton, Argentina. Geoscience Frontiers 5, 43-52.

Chernicoff, C.J., Pereyra, F., Santos, J.O.S., Zappettini, E.O., 2015. Primeras edades U-Pb SHRIMP del Cratón del Río de la Plata en el subsuelo del área Metropolitana de Buenos Aires. Rev. Asoc. Geol. Argent. 72, 575-577.

Cingolani, C.A., 2011. The Tandilia system of Argentina as a southern extension of the Río de La Plata craton: an overview. Int. J. Earth Sci. 100, 221-242.

Cingolani, C.A., Hartmann, L.A., Santos, J.O.S., McNaughton, N.J., 2002. U-Pb SHRIMP dating of zircons from the Buenos Aires Complex of the Tandilia belt, Río de la Plata craton, Argentina. $15^{\circ}$ Congreso Geológico Argentino 1, 149-154.

Clayton, R.N., Mayeda, T.K., 1963. The use of bromine pentafluoride in the extraction of oxygen from oxides and silicates for isotopic analysis. Geochem. Cosmochim. Acta $27,43-52$.

Crespo, E., Luque, J., Fernández-Rodríguez, C., Rodas, M., Díaz-Azpiroz, M., FernándezCaliani, J.C., Barrenechea, J.F., 2004. Significance of graphite occurrences in the Aracena metamorphic belt, Iberian Massif. Geol. Mag. 141, 687-697.

Dalla Salda, L.H., Bossi, J., Cingolani, C., 1988. The Río de la Plata cratonic region of Southwestern Gondwana. Episodes 11, 263-269.

Dalla Salda, L.H., de Barrio, R.E., Echeveste, H., Fernández, R., 2005. El basamento de las Sierras de Tandilla. In: de Barrio, R.E., Etcheverry, R., Caballé, M.F., Llambías, E.J. (Eds.), Geología y Recursos minerales de la Provincia de Buenos Aires. Relatorio del $26^{\circ}$ Congreso Geológico Argentino, La Plata, pp. 32-50.

Delpino, S.H., 2000. Evolución metamórfica del sector nororiental del basamento de Tandilia, Argentina: metamorfismo en facies granulita y anatexis cortical. 
Universidad Nacional del Sur Ph.D. thesis.

Delpino, S.H., Dristas, J.A., 2008. Dolomitic marbles and associated calc-silicates, Tandilia belt, Argentina: geothermobarometry, metamorphic evolution, and P-T path. J. S. Am. Earth Sci. 23, 147-175

Dipple, G.M., Gerdes, M.L., 1998. Reaction-Infiltration feedback and hidrodynamics at the skarn front. In: In: Lentz, D. (Ed.), Mineralized Intrusion-related Skarn Systems, vol. 26. Mineralogical Association of Canada, Short Course Series, pp. 71-90.

Dissanayake, C.B., Chandrajith, R., Boudou, J.P., 2000. Biogenic graphite as a potential geomarker. Application to continental reconstructions of Pan-African Gondwana terrains. Gondwana Res. 3, 405-413.

Droop, G.T.R., 1987. A general equation for estimating Fe3 + in ferromagnesian silicates and oxides from microprobe analysis, using stoichiometric criteria. Miner. Mag. 51, 431-437.

Franchini, M., Lira, R., Sfragulla, J., 1998a. Zonación mineralógica y evolución de los fluidos en el skarn Copina, provincia de Córdoba (64³9' O-31³0'S). Rev. Asoc. Geol. Argent. 53, 197-211.

Franchini, M., Lira, R., Sfragulla, J., 1998b. El skarn Cañada del Puerto (3125' LS$64^{\circ} 54^{\prime} \mathrm{LO}$ ), provincia de Córdoba: otro ejemplo de metasomatismo generado por fluidos ricos en agua, hidrógeno y flúor. Rev. Asoc. Geol. Argent. 53, 247-260.

Franchini, M., Lira, R., Sfragulla, J., 1999. Los skarns San Marcos Sierra y La Falda: geología, mineralogía y composición de los fluidos hidrotermales. Comparación con otros skarns de las Sierras Pampeanas Orientales de Córdoba. Rev. Asoc. Geol. Argent. 54, 420-435.

Gaucher, C., Frei, R., Chemale Jr., F., Frei, D., Bossi, J., Martínez, G., Chiglino, L., Cernuschi, F., 2011. Mesoproterozoic evolution of the Río de la Plata craton in Uruguay: at the heart of Rodinia? Int. J. Earth Sci. 100 (2), 273-288.

Goldstein, R.H., Reynols, T.J., 1994. Systematics Fluid Inclusions in Diagenetic Minerals, vol. 31 Society for Sedimentary Geology, Society of Economic Paleontologists and Mineralogists Short Course.

Gómez Peral, L.E., 2008. Petrología y diagénesis de las unidades sedimentarias precámbricas de Olavarría, Provincia de Buenos Aires. Universidad Nacional de La Plata Ph.D. thesis.

Groat, L.A., Hawthorne, F.C., Ercit, T.S., 1992. The role of fluorine in vesuvianite: a crystal structure study. Can. Mineral. 30, 1065-1075.

Groat, L.A., Hawthorne, F.C., 1998. Diffuse reflections and the symmetry of vesuvianite. Phase Transitions 67, 137-151.

Halpern, M., Umpierre Urquhart, M., Linares, E., 1970. Radiometric ages of crystalline rocks from southern South America, as relate to Gondwana and Andean geologic provinces. In: $4^{\circ}$ Upper Mantle Symposium. Petrología y Volcanismo, Buenos aires, pp. 345-356.

Han, T.M., Runnegar, B., 1992. Magascopic eukaryotic algae from 2.1 billion year old Negaunee Iron-Formation, Michigan. Science 257, 232-235.

Hart, S.R., Krogh, T.E., Davis, G.L., Aldrich, L.T., Minizaga, R., 1965. A geochronological approach to the continental drift hypothesis. Carnegie Institute Whashington Yearbook 65, 57-59.

Hartmann, L.A., Santos, J.O.S., Bossi, J., Campal, N., Schipilov, A., McNaughton, N.J., 2002a. Zircon and titanite U-Pb SHRIMP geochronology of Neoproterozoic felsic magmatism on the eastern border of the Río de la Plata craton, Uruguay. J. S. Am. Earth Sci. 15, 229-236.

Hartmann, L.A., Santos, J.O.S., Cingolani, C.A., McNaughton, N.J., 2002b. Two paleoproterozoic orogenies in the evolution of the Tandilia belt, Buenos Aires, as evidenced by zircon U-Pb SHRIMP geochronology. Int. Geol. Rev. 44, 528-543.

Hoefs, J., 2009. Stable Isotope Geochemistry, $6^{\circ}$ edition. Springer-Verlag, Berlin.

Hurai, V., Huraiová, M., Slobodnik, M., Thomas, R., 2015. Geofluids: Developments in Microthermometry, Spectroscopy, Thermodynamics, and Stable Isotopes. Elsevier, London.

Iacumin, M., Piccirillo, E., Girardi, V., Teixeira, W., Bellieni, G., Echeveste, H., Fernández, R., Pinese, J., Ribot, A., 2001. Early proterozoic calc-alkaline and middle proterozoic tholeiitic dyke swarms from central-eastern Argentina. Petrology, geochemistry, SrNd isotopes and tectonic implications. J. Petrol. 42, 2109-2143.

Kretz, R., 1983. Symbols for rock-forming minerals. Am. Mineral. 68, 277-279.

Lafuente, B., Downs, R.T., Yang, H., Stone, N., 2015. The power of database: the RRUFF project. In: Ambruster, T., Danisi, R.M. (Eds.), Highlights in Mineralogical Crystallography. Berlin, Germany, pp. 1-33.

Lajoinie, M.F., 2015. Geología y Geoquímica del skarn San Miguel, Sistema de Tandilla, provincia de Buenos Aires. Universidad Nacional de La Plata Ph.D. thesis.

Lajoinie, M.E., Canafoglia, M.E., Lanfranchini, M.E., Etcheverry, R.O., Salvioli, M.A., 2012. Estudio de la especie mineral vesubianita mediante diferentes técnicas físicoquímicas. J. Argentine Chem. Soc. Anales de la Asociación Química Argentina $99,1-2$.

Lajoinie, M.F., Lanfranchini, M.E., Etcheverry, R.O., Recio, C., 2013. Zonación mineral vinculada a procesos geoquímicos en el skarn San Miguel, Sierras Septentrionales de la provincia de Buenos Aires. Rev. Asoc. Geol. Argent. 70, 402-412.

Lajoinie, M.F., Etcheverry, R.O., Lanfranchini, M.E., Cabana, C., 2014a. Geología, geoquímica y génesis de diques proterozoicos del área de San Miguel, Sierras Septentrionales de la provincia de Buenos Aires. Rev. Asoc. Geol. Argent. 71, 404-415.

Lajoinie, M.F., Lanfranchini, M.E., Etcheverry, R.O., Recio, C., 2014b. Primeros registros del "evento Lomagundi-Jatuli" en mármoles del basamento de las Sierras Septentrionales de la provincia de Buenos Aires, Cratón del Río de la Plata. Rev. Asoc. Geol. Argent. 71, 585-597.

Lajoinie, M.F., Lanfranchini, M.E., Etcheverry, R.O., 2017a. Basamento paleoproterozoico del área de San Miguel, Sierras Septentrionales de la provincia de Buenos Aires. Registro de una cuenca de retroarco en el margen sur del Cratón del Río de la Plata. Actas del $20^{\circ}$ Congreso Geológico Argentino. San Miguel de Tucumán (Tucumán), pp. $42-44$.
Lajoinie, M.F., Lanfranchini, M.E., Etcheverry, R.O., Benítez, M., de la Cal, H.G., 2017b. Estudios geoquímicos de Tierras Raras e Itrio en rocas de la Formación El Cortijo, Sierras Septentrionales de la provincia de Buenos Aires. Actas del $20^{\circ}$ Congreso Geológico Argentino. San Miguel de Tucumán (Tucumán), pp. 33-35.

Lajoinie, M.F., Lanfranchini, M.E., Etcheverry, R.O., Recio, C., Benítez, M., 2017c. Skarn San Miguel, Sierras Septentrionales de la provincia de Buenos Aires: Zonación isotópica $\delta^{18} \mathrm{O}$ en el proceso metasomático. Buenos Aires. Actas del $20^{\circ}$ Congreso Geológico Argentino, San Miguel de Tucumán (Tucumán) 36-41.

Lajoinie, M.F., Lanfranchini, M.E., Recio, C., Alcides, S.N., Cingolani, C.A., Ballivián Justiniano, C.A., Etcheverry, R.O., 2018. The Lomangundi-Jatuli carbon isotopic event recorded in the marble basement of the Tandilia System basement, Río de la Plata Craton. Precambrian Res. https://doi.org/10.1016/j.precamres.2018.03.012.

Linares, E., González, R., 1990. Catálogo de edades radimétricas de la República Argentina 1957-1987. Publicaciones Especiales de la Asociación Geológica Argentina (serie B).

Luque, F.J., Pasteris, J.D., Wopenka, B., Rodas, M., Barrenechea, J.F., 1998. Natural fluid deposited graphite: mineralogical characteristics and mechanisms of formation. Am. J. Sci. 298, 471-498.

Luque, F.J., Ortega, L., Berrenechea, J.F., Millward, D., Beyssac, O., Huizenga, J.M., 2009. Deposition of highly crystalline graphite from moderate-temperature fluids. Geology 37, 275-278.

Luque, F.J., Crespo-Feo, E., Barrenechea, J.F., Ortega, L., 2012. Carbon isotopes of graphite: implications on fluid history. Geoscience Frontiers 3, 197-207.

Mallmann, G., Chemale Jr., F., Ávila, J.N., Kawashita, K., Armstrong, R.A., 2007. Isotope geochemistry and geochronology of the nico pérez terrane, Río de la Plata craton, Uruguay. Gondwana Res. 12, 489-508.

Marchese, H.G., Di Paola, E., 1975. Miogeosinclinal Tandil. Rev. Asoc. Geol. Argent. 30, $161-179$.

Martínez, J.C., Massonne, H.J., Dristas, J.A., Theye, T., Graff, A.A., 2016 Paleoproterozoic migmatitic gneisses from the Tandilia belt (Argentina), Río de la Plata craton, record cooling at deep crustal levels. J. S. Am. Earth Sci. 67, 201-220.

Martínez, J.C., Massonne, H., Frisicale, M., Dristas, J., 2017. Trans-Amazonian U-Th-Pb monazite ages and P-T-d exhumation paths of garnet-bearing leucogranite and migmatitic country rock of the southeastern Tandilia belt, Rio de la Plata craton in Argentina. Lithos 274-275, 328-348.

Massonne, H.J., 2012. Formation of amphibole and clinozoisite-epidote in eclogite owing to fluid infiltration during exhumation in a subduction channel. J. Petrol. 53, 1969-1998.

Meinert, L., Dipple, G., Nicolescu, S., 2005. World skarn deposits. Economic Geology, $100^{\circ}$ Aniversary 299-336.

Melezhik, V.A., Fallick, A.E., Kuznetsov, A.B., 2005. Palaeoproterozoic, rift-related, ${ }^{13} \mathrm{C}-$ rich, lacustrine carbonates, NW Russia-Part 2: global isotope signal recorded in the lacustrine dolostones. Trans. R. Soc. Edinb. Earth Sci. 95, 423-444.

Nash, J.T., 1976. Fluid Inclusion Petrology-data from Porphyry Copper Deposits and Application to Exploration. U. S. Geology Survey Paper 907-D.

Nokleberg, W.J., 1973. CO2 as a source of oxygen in the metasomatism of carbonates. Am. J. Sci. 273, 498-514.

Oriolo, S., Oyhantçabal, P., Basei, M.A.S., Wemmer, K., Siegesmund, S., 2016a. The nico pérez terrane (Uruguay): from Archean crustal growth and connections with the Congo craton to late neoproterozoic accretion to the Río de la Plata craton. Precambrian Res. 280, 147-160.

Oriolo, S., Oyhantçabal, P., Wemmer, K., Basei, M.A.S., Benowitz, J., Pfänder, J., Hannich, F., Siegesmund, S., 2016b. Timing of deformation in the Sarandí del Yí Shear Zone, Uruguay: implications for the amalgamation of western Gondwana during the Neoproterozoic Brasiliano-Pan-African Orogeny. Tectonics 35, 754-771.

Oyhantçabal, P.B., Cingolani, C.A., Wemmer, K., Siegesmund, S., 2018. The Río de la Plata craton of Argentina and Uruguay. In: Siegesmund, S. (Ed.), Geology of Southwest Gondwana. Regional Geology Reviews, . http://doi.org/10.1007/978-3319-68920 4.

Pankhurst, R.B., Ramos, A., Linares, E., 2003. Antiquity of the Río de la Plata craton in Tandilia, southern Buenos Aires province, Argentina. J. S. Am. Earth Sci. 16, 5-13.

Pasteris, J.D., Wopenka, B., 2003. Necessary, but not sufficient: Raman identification of disordered carbon as signature of ancient life. Astrobiology 3, 727-738.

Perrin, J., Vielzeuf, D., Laporte, D., Ricolleau, A., Rossman, G.R., Floquet, N., 2016. Raman characterization of synthetic magnesian calcites. Am. Mineral. 101, 2525-2538.

Poiré, D.G., 1987. Mineralogía y sedimentología de la Formación Sierras Bayas en el núcleo septentrional de las sierras homónimas, partido de Olavarría, provincia de Buenos Aires. Universidad Nacional de La Plata Ph.D. thesis.

Poiré, D.G., Spalletti, L.A., del Valle, A., 2003. The Cambrian-Ordovician siliciclastic platform of the Balcarce Formation (Tandilia System, Argentina): facies, trace fossils, palaeoenvironments and sequence stratigraphy. Geol. Acta 1, 41-60.

Quartino, B., Villar Fabre, J., 1967. Geología y petrología del basamento de Tandil y Barker, provincia de Buenos Aires, a la luz del estudio de localidades críticas. Rev. Asoc. Geol. Argent. 22, 223-251.

Rantitsch, G., Lämmerer, W., Fisslthaler, E., Mitsche, S., Kaltenböck, H., 2016. On the discrimination of semi-graphite and graphite by Raman spectroscopy. Int. J. Coal Geol. https://doi.org/10.1016/j.coal.2016.04.001.

Roedder, E., 1962. Ancient fluids in crystals. Sci. Am. 207, 38-47.

Roedder, E., 1971. Metastability in fluid inclusions. Soc. Mining Geol. Jap. Spec. Issue 3, 327-334.

Roedder, E., 1984. Fluid inclusions. Mineralogy society of America. Rev. Mineral. 12.

Ruiz, R., Giraudo de Lucio, I., 2017. Caracterización de las fases orgánicas e inorgánicas presentes en cuarzos tipo Herkimer de la Fm. Auquilco mediante Espectroscopia Raman. Actas del $20^{\circ}$ Congreso Geológico Argentino, San Miguel de Tucumán (Tucumán), pp. 110-116. 
Santos, J.O.S., Chernicoff, C.J., Zappettini, E.O., McNaughton, N.J., Greau, Y., 2017a Geochronology of Martín García, sola, and dos hermanas Islands (Argentina and Uruguay) within the Río de la Plata craton: presence of rhyacian, statherian, an ectasian rocks. J. S. Am. Earth Sci. 80, 207-228

Santos, J.O.S., Chernicoff, C.J., Zappettini, E.O., McNaughton, N.J., Hartmann, L.A., 2017b. Large geographic and temporal extensions of the Río de la Plata Craton, South America, and its metacratonic eastern margin. Int. Geol. Rev. 1-30. https://doi.org/ 10.1080/00206814.2017.1405747.

Santosh, M., Wada, H., 1993. A carbon isotope study of graphite from the Kerala Khondalite Belt, Southern India: evidences for $\mathrm{CO} 2$ infiltration in granulites. J. Geol. 101, 643-651.

Schidlowski, M., 1995. Early terrestrial life: problems of the oldest record. In: ChelaFlores, J., Chadna, M., Negron-Mendoza, A., Oshima, T. (Eds.), Chemcal Evolution: Self-organization of the Macromolecules of Life. A Deepack Publishing, Hampton, Virginia, U.S.A., pp. 65-80.

Schidlowski, M., Aharon, P., 1992. Carbon cycle and carbon isotope record: geochemical impact of life over $3.8 \mathrm{Ga}$ of earth history. In: Schidlowski, M. (Ed.), Early Organic Evolution: Implications for Mineral and Energy Resources. Springer-Verlag, Berlin, Heidelberg, pp. 147-175.

Sharp, Z.D., 1990. A laser-based microanalytical method for the in situ determination of oxygen isotope ratios of silicates and oxides. Geochem. Cosmochim. Acta 54, 1353-1357.

Shepherd, T.J., Rankin, A.H., Alderton, D.H., 1985. A Practical Guide to Fluid Inclusion Studies. Blackie and Sons, pp. 239.

Tazaki, K., Ferris, E.G., Wiese, R.G., Fyfe, W.S., 1992. Iron and graphite associated with fossil bacteria in chert. Chem. Geol. 95, 313-325.

Teixeira, W., D'Agrella-Filho, M.S., Hamilton, M.A., Ernst, R.E., Girardi, V.A.V., Mazzucchelli, M., Bettencourt, J.S., 2013. U-Pb (ID-TIMS) baddeleyite ages and paleomagnetism of 1.79 and $1.59 \mathrm{Ga}$ tholeiitic swarms, and position of the Río de la Plata Craton within the Columbia supercontinent. Lithos 174, 157-174.
Teruggi, M.E., Kilmurray, J.O., Dalla Salda, L.H., 1973. Los dominios tectónicos de la región de Tandil. An. Soc. Cient. Argent. 295, 81-94.

Teruggi, M.E., Leguizamón, M.A., Ramos, V.A., 1988. Metamorfitas de bajo grado con afinidades oceánicas en el basamento de Tandil: su implicancia geotectónica, provincia de Buenos Aires. Rev. Asoc. Geol. Argent. 43, 366-374.

Tsu, R., Gonzalez, H., Hernandez, I., 1978. Observation of splitting of the E2g mode and two-phonon spectrum in graphite. Solid Stage Commun. 27, 507-510.

Valley, J.W., 2003. Oxygen isotopes in zircon. In: In: Hanchar, J.M., Hoskin, P.W.O. (Eds.), Zircon. Reviews in Mineralogy and Geochemistry, vol. 53. pp. 343-385.

Varela, R., Cingolani, C.A., Dalla Salda, L.H., 1988. Geocronología rubidio-estroncio en granitoides del basamento de Tandil, provincia de Buenos Aires, Argentina. 2 Jornadas Geológicas Bonaerenses, Bahía Blanca. Comisión de Investigaciones Científicas de la provincia de Buenos Aires, pp. 291-305.

Velasco, F., 2004. Introducción al estudio de inclusiones fluidas. $23^{\circ}$ Curso Latinoamericano de Metalogenia, Mendoza, Argentina.

Wopenka, B., Pasteris, J.D., 1993. Structural characterization of kerogens to granulite facies graphite: applicability of Raman microprobe spectroscopy. Am. Mineral. 78, 533-557.

Zhang, Y.G., Frantz, J.D., 1987. Determination of homogenization temperatures and densities of supercritical fluids in the system $\mathrm{NaCl}-\mathrm{KCl}-\mathrm{CaCl}_{2}-\mathrm{H}_{2} \mathrm{O}$ using synthetic fluid inclusions. Chem. Geol. 64, 335-350.

Zheng, Y.F., 1993a. Calculation of oxygen isotope fractionation in anhydrous silicate minerals. Geochem. Cosmochim. Acta 57, 1079-1091.

Zheng, Y.F., 1993b. Calculation of oxygen isotope fractionation in hydroxyl-bearing silicates. Earth Planet Sci. Lett. 12, 247-263.

Zheng, Y.F., 1999. Oxygen isotope fractionation in carbonate and sulfate minerals. Geochem. J. 33, 19-126.

Zimmermann, U., Spalletti, L.A., 2009. Provenance of the lower palaeozoic Balcarce Formation (Tandilia system, Buenos Aires province, Argentina): implications for palaeogeographic reconstructions of SW gondwana. Sediment. Geol. 219, 7-23. 